Boletín de la Sociedad Geológica Mexicana

VOLUMEN 62, NÚM. 2, 2010, P. 281-304

\title{
Sediment transport trends in Bahía Concepción, Baja California Sur, Mexico, based on textural parameters and heavy mineral concentrations
}

\author{
Oscar González-Yajimovich ${ }^{1, *}$, José Luis Perez-Soto ${ }^{1}$, Guillermo E. Avila-Serrano ${ }^{1}$, Keith \\ Meldahl $^{2}$ \\ ${ }^{1}$ Facultad de Ciencias Marinas, Universidad Autónoma de Baja California, Ap. Postal 76 Ensenada, Baja California México 22800. \\ ${ }^{2}$ Department of Physical Sciences, Mira Costa College, 1 Barnard Drive, Oceanside, CA 92056. \\ *yajimo@uabc.edu.mx
}

\begin{abstract}
The dispersion pattern of the modern sediments of Bahía Concepción, Baja California Sur, Mexico was obtained based on the spatial trends of their textural properties and heavy mineral content. The McLaren and Bowles and LeRoux models were applied to a sediment texture data set. The McLaren and Bowles method was the most appropriate for the present study due to the elongated nature of the bay and sampling design, but it was complemented by the LeRoux model, providing in some cases a lateral transport component. Seven heavy minerals were identified and their sources were located with the aid of Principal Component Analysis. Two main sources were evident based on the spatial textural trends; one located between Playa Santispac and Punta Santa Bárbara, and the other adjacent to the Cadejé Basin. A bi-directional transport pattern was found at the mouth of the bay with sediment being exported near the margins and imported through the deeper central portion. Transport along the western margin was mostly towards the head of the bay, and towards the north along the eastern margin. In both cases the transport trends indicate a component of transport toward the deeper parts of the bay. A good agreement was found among the three methods in identifying the clastic-sediment sources and their main transport directions.
\end{abstract}

Keywords: Gulf of California, bathymetry, modern sediments, heavy minerals, provenance, modeling of sediment load.

\section{Resumen}

Se obtuvo el patrón de dispersión de los sedimentos superficiales de Bahía Concepción, Baja California Sur, con base en las tendencias espaciales de sus propiedades texturales y contenido de minerales pesados. Se aplicaron los modelos de McLaren y Bowles y LeRoux a un conjunto de datos de textura de sedimentos. El método de McLaren y Bowles fue el más apropiado para el presente estudio debido a la naturaleza elongada de la bahía y diseño de muestreo, pero el método de LeRoux lo complementa pues provee en algunos casos una componente lateral. Se identificaron siete minerales pesados y sus fuentes fueron localizadas con la ayuda de Análisis de Componentes Principales. Basado en las tendencias espaciales de la textura, se hicieron evidentes dos fuentes principales; una localizada entre Playa Santispac y Punta Santa Bárbara, y la otra adyacente a Cuenca Cadejé. Se identificó un patrón de transporte bidireccional en la boca de la bahía con sedimentos exportándose cerca de las márgenes e importándose a través de la parte central más profunda. El transporte a lo largo de la margen oeste fue en su mayor parte hacia la cabecera de la bahía y a lo largo de la margen este hacia el norte. En ambos casos las tendencias de transporte indican una componente de transporte hacia las partes profundas de la bahía. Se encontró que los tres métodos tienen buena concordancia al identificar las fuentes de sedimento clástico y las direcciones principales de transporte. 
Palabras clave: Golfo de California, batimetría, sedimentos modernos, minerales pesados, proveniencia, modelado de transporte sedimentario.

\section{Introduction}

Bahía Concepción (Figure 1) is a small rift basin in the borderland of the Gulf of California (Nava-Sánchez et al., 2001) and has been proposed as a potential analog for Neogene shallow marine rift basins, for example, Loreto basin, which developed during the early stages of the Neogene (Meldahl et al., 1997; Pérez-Soto, 1998) and has similar stratigraphic facies. The results of studies of sedimentary dynamics of these rift basins could be a useful tool in interpreting stratigraphic facies.

Recently it has been suggested that the source-sink approach in this type of environment provides a framework for the understanding and prediction of flows and chemical transformations of the sediments and solutes in the system and the resulting sedimentary sequences. In this way, the interaction of the source, transport and destination of the sedimentary components with the climate and tectonic processes establishes the distribution of the sedimentary constituents in these environments (Sánchez et al., 2008). Therefore it is relevant to establish the dynamic sedimentary processes and the sources of modern materials. Bahía Concepción is considered an area of great potential for tourism development but at this time only small communities occupy its shores, and this provides a good opportunity to implement an urban planning strategy. There are however very few studies on the environmental significance that it would have on this area (LechugaDevéze et al., 2000; López-Cortés et al., 2003; Camprubí et al., 2008; Gutierrez de Velasco et al., 2006; Meldahl et al., 1997; Morquecho and Lechuga-Devéze, 2003; Ponte et al., 2006; Rodríguez-Meza et al., 2009). Sediment transport paths and sea floor mapping are essential and required in environmental studies to determine, for example, the possible dispersal patterns of contaminants (Duman et al., 2004), dispersion of larvae in aquiculture programs or of red tide producing dynoflagellate cysts (Morquecho and Lechuga-Devéze, 2003), management and conservation of shores and ecological reserve design (Wright and Scholz, 2005). An excellent discussion of the sediment-transport environmental implications can be found in Sánchez et al. (2008).

Sediment transport models have been proposed that identify the direction of particle movement by using the spatial trends of their textural properties (e.g., McLaren and Bowles, 1985; Gao and Collins, 1992, 1994; LeRoux, 1994a, b; Sánchez et al., 2008). This type of analysis has been used to determine the sediment transport trends in different environments such as coastal lagoons estuaries and the continental shelf. Two textural trends models were applied to a sediment texture data set in this investigation (McLaren and Bowles, 1985; LeRoux, 1994a, b).

Heavy mineral contents and trends were identified to provide an independent control on the textural models. By quantifying the relative concentrations of different heavy minerals (accessory components of detrital sediments with densities above 2.89), one may be able to reconstruct and to interpret the history of sediment from the initial erosion of parent rocks to the final burial of their detritus, i.e., to unravel the line of descent or lineage of the sediment under investigation (Mange-Rajetzky, 2003). The ultimate goal is to deduce the characteristics of source areas from measurements of compositional and textural properties of sediments, supplemented by information from other lines of evidence (Wright and Scholz, 2005; Mange-Rajetzky, 2003). Van Andel's (1964) monumental work on the sediment sources and their dispersal patterns focused on the heavy mineral content in order to define provenance and found that from the Bahía de $\mathrm{La} \mathrm{Paz}$, in the southern portion of the peninsula, to just north of Bahía Concepción the volcanics of the Comondú Group are a source of heavy minerals with a dominance of augite. Van Andel (1964) named this area "The augite province of Baja California". Baba et al. (1991) identified the sources and dispersal of sediments in the Gulf of California and found patterns similar to those described by Van Andel (1964).

We report here on the dispersion of surface sediments by means of sediment textural trends and heavy mineral dispersion in Bahía Concepción, and provide a high resolution bathymetric survey of the bay.

The aim of this study is to provide a sediment transport scheme to be use for future studies, particularly those of environmental monitoring and management, and as a potential tool for the interpretation of stratigraphic facies.

\section{Study area}

Bahía Concepción is an enclosed shallow bay about $40 \mathrm{~km}$ long and varies from 5 to $10 \mathrm{~km}$ wide. The deepest parts are associated with a main channel that switches from the east at the northern part of the bay to the west in the southern part of the bay (Gonzalez-Yajimovich and PérezSoto, 1998). The bay is open to the Gulf of California at its north end (Figure 1). The eastern side of the bay is formed by the 10 to $15 \mathrm{~km}$-wide Concepción Peninsula, which rises to elevations of over $700 \mathrm{~m}$. Distinct geomorphic differences characterize the eastern and western shores of the bay. The eastern bay's shore (western side of the Concepción Peninsula) has a well-developed, 30 km-long 


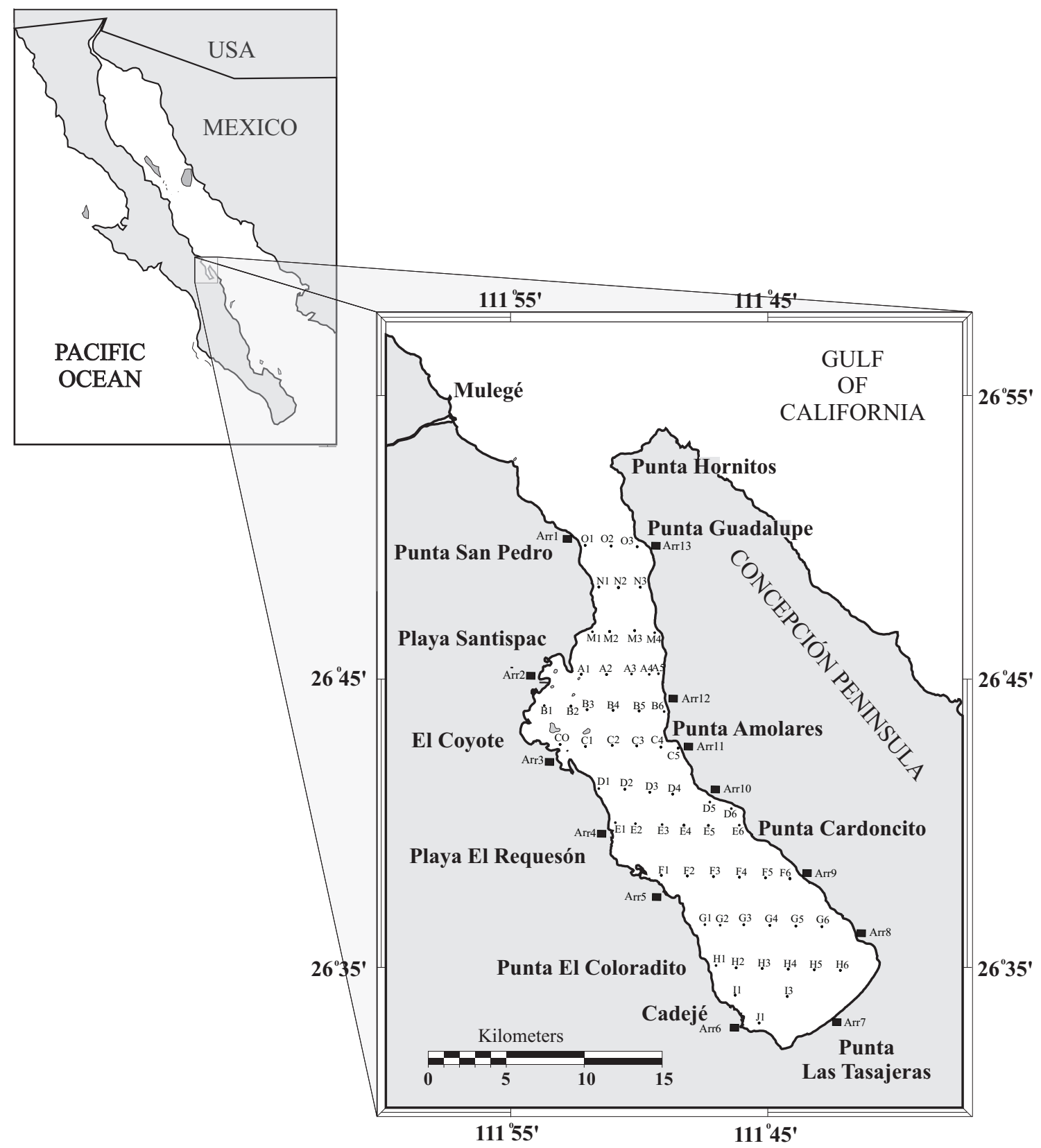

Figure 1. Location of Bahía Concepción, Baja California Sur, showing sample stations. Sediments were collected with a Petit Ponar grab sampler from a boat along east-west transects (dots) and by hand at the arroyos (squares).

continuous alluvial slope or "bajada" backed by short, steep canyons that rarely extend more than $5 \mathrm{~km}$ back into the Concepción Peninsula. The western shore of the bay is dominated by steep rocky shorelines rising abruptly from the water. This rugged shoreline is interrupted in several places by long deep canyons, the largest of which extend inland 10 to $25 \mathrm{~km}$. In distinct contrast to the extensive bajada on the east side, alluvial fans on the west side occur only at the mouths of these large canyons. In embayments along the western shore there are several sheltered pocket bays rich in carbonate sand and several mangrove swamps.
The southern end of the bay is a low-lying alluvial plain that rises gradually away from the bay toward the southeast.

Bedrock geology surrounding the bay consists of a basement complex of Cretaceous schistose and granitic rocks overlain unconformably by Oligocene and Miocene volcanics of the Comondú Group (McFall, 1968; LedesmaVázquez and Johnson, 2001; Camprubí et al., 2008). McFall (1968) recognizes six vertically stacked Comondú formations in the region (Figure 2). The $\sim 300 \mathrm{~m}$ Salto Formation is the oldest and consists of red tuffaceous crossbedded sandstone and interbedded tuffs. On top of the Salto 


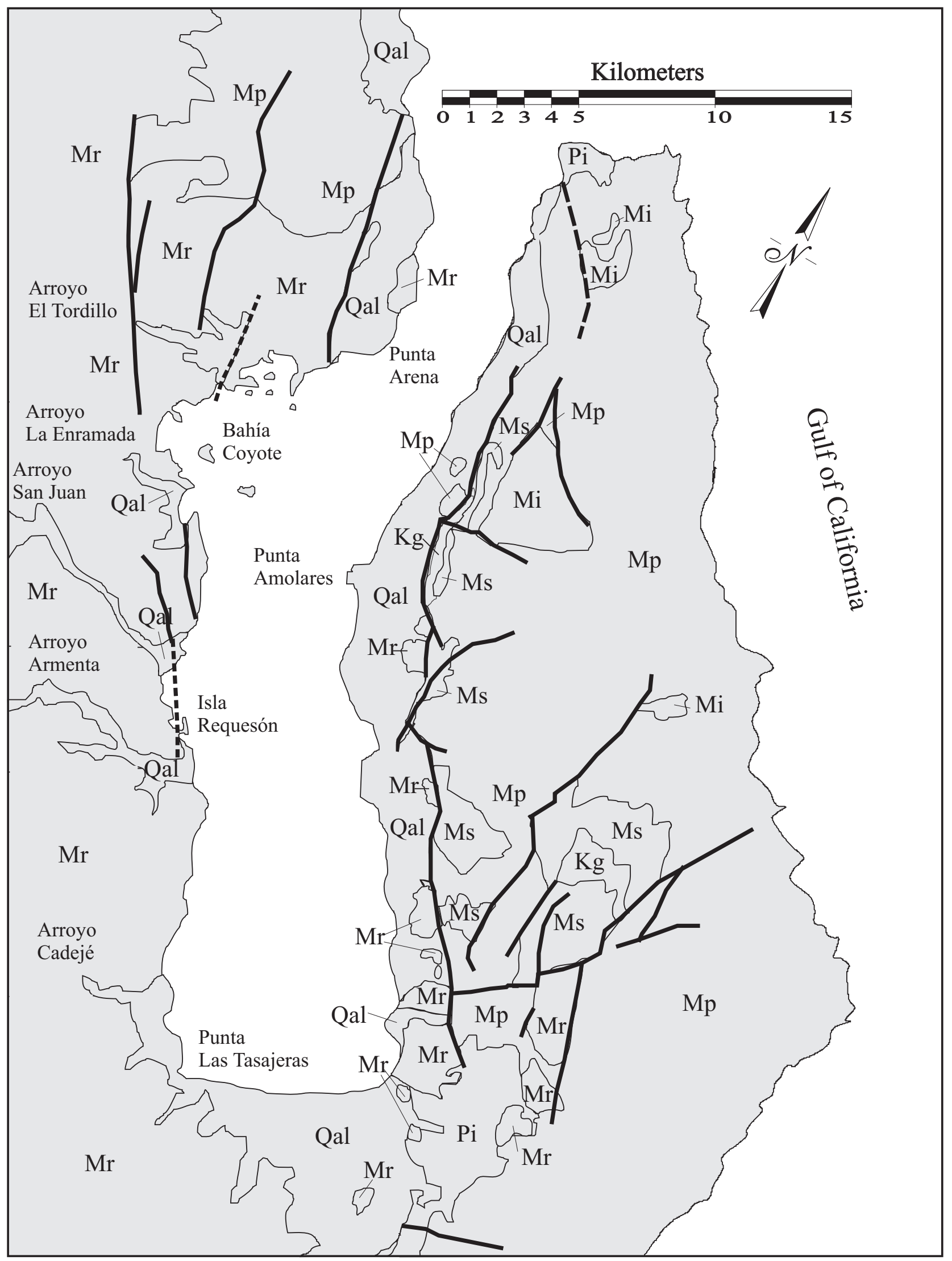

Figure 2. Geologic map of Bahía Concepción, modified from McFall (1968), showing the main drainages (arroyos). Heavy lines are faults; light lines are shorelines or contacts between major rock units. $\mathrm{Qal}=$ quaternary alluvium; $\mathrm{Pi}=\mathrm{Pliocene}$ Infierno Formation; $\mathrm{Mr}=\mathrm{Miocene} \mathrm{Ricason} \mathrm{Formation} ; \mathrm{Mi}=$ Miocene intrusions; $\mathrm{Mp}=$ Miocene Pelones Formation; $\mathrm{Ms}=$ Miocene Salto Formation; Kg = Cretaceous basement. 
Formation dominating the bay is the Pelones Formation that consists of 2,000 $\mathrm{m}$ of volcanic agglomerates, basalt flows, and tuffs, with some conglomerate and tuffaceous sandstone beds. In some areas the Pelones Formation is topped by one or more of the following formations: the Minitas Formation (30 to $150 \mathrm{~m}$ of coarse tuffaceous conglomerate), the Pilares Formation (100 $\mathrm{m}$ of aphanitic and porphyritic basalt), and the Hornillos Formation (150 m of coarse tuffaceous conglomerate). The Ricasón Formation dominates the western side of the bay and consists of more than $1,500 \mathrm{~m}$ of interbedded basalt flows, agglomerates and tuffs.

Gabbro stocks and dykes intrude the Pelones Formation and older rocks. Several tonalite intrusions also occur in the area, the largest being the Cerro Blanco stock (McFall, 1968).

A thin veneer of conglomerates, sandstones, siltstones and coquinas can be found over the Comondú Group. These are of the Pliocene Infierno Formation (Ledesma-Vázquez et al., 1997) and crop out widely over the southeastern area of the bay and at the northern end of the Concepción Peninsula.

Meldahl et al. (1997) found that Holocene sediments accumulate in seven distinct depositional environments in the bay: alluvial fans, fan-deltas, coastal interfan flats, pocket bays, mangrove swamps, nearshore shelf, and offshore shelf.

The central basin of the bay is mainly composed of fine green mud (Meldahl et al., 1997; Rodríguez-Meza et al., 2009), and the currents produced by tides are of low intensity (Obeso Nieblas et al., 1996; Gutierrez de Velasco et al., 2006; Rodríguez-Meza et al., 2009). These characteristics suggest that Bahía Concepción acts as a large sediment trap and thus the bathymetry must play an important role in the distribution of sediment.

Caliskan and Valle-Levinson (2008) reported surface waves produced by winds that blow predominantly from the northwest in the winter and from south to southeast in the summer. They recorded surface waves with periods of $\sim 3,7$ and 15 seconds at the mouth of the bay, but only waves with periods of $\sim 3$ seconds at the head of the bay. They observed that energetic long-period waves entering at the mouth were dissipated within the bay and were not observed at the head of the basin, concluding that these energetic waves were attenuated by wave blocking owing to the change of coastline orientation of the bay. Ponte et al. (2006) used drifters at three different levels and found a vertically stratified circulation close to the entrance of the bay and a vertically homogeneous cyclonic circulation in the south of the bay. Close to the mouth, the surface currents were to the south. At a depth of $10 \mathrm{~m}$, however, the drifters oscillated around their release positions and along the axis of the channel while being slowly advected to the south. At $20 \mathrm{~m}$, the currents were to the north, out of the bay. On the south transect, drifters deployed at the same horizontal position but at different depths follow similar trajectories: a cyclonic pattern around the end of the bay, with most drifters ending their trajectories at the southwest corner.
Obeso Nieblas et al. (1996) measured and modeled the tides in Bahía Concepción and found a semi-diurnal type with a range of $59 \mathrm{~cm}$ at the entrance and $75 \mathrm{~cm}$ at the head during April of 1992. The bay responded almost instantly to the tide with no lag between the entrance and the head. The current recorded at the entrance during February of $1994 \mathrm{had}$ a maximum magnitude of $29.5 \mathrm{~cm} / \mathrm{s}$, and a northwest-southeast direction. During December of 1992 it had a maximum magnitude of $30 \mathrm{~cm} / \mathrm{s}$, and a northwestsoutheast direction. Northwesterly winds were recorded at 3 m/s during February 1994 and 4.3 m/s during April 1992.

Gutierrez de Velasco et al. (2006) investigated the tidal and wind forcing and found a diurnal character tide with little vertical variation throughout the bay and a $1 \mathrm{~m}$ range during spring tide. They found an almost instantaneous tide along the bay that can be explained by the ratio of the Gulf of California diurnal tide wavelength to the bay's length. Their results of wind measurements show fall and winter seasons being dominated by northwesterly wind events with magnitudes in excess of $10 \mathrm{~ms}^{-1}$ and 3 to 7 day duration, with most of these events having a strong diurnal component. Spring and summer conditions exhibit $2 \mathrm{~ms}-1$ southeasterly wind with daily periodicities and occasional $10 \mathrm{~ms}^{-1}$ southeasterly events of 3 to 7 day duration.

\section{Methods}

During March 1994, 58 superficial sediment samples were collected from different sedimentary environments (fan-deltas, pocket bays, mangrove swamps, nearshore shelf and offshore shelf) in Bahía Concepción, Baja California Sur, México (Figure 1). The samples were obtained with a Petit Ponar Grab from a small inflatable boat along eastwest transects across the bay, and by SCUBA diving along transects perpendicular to the shore. Samples were also obtained by hand at the mouths of 13 arroyos. The sampling site coordinates were recorded with a Garmin GPS, model 2000. At each station $\sim 500 \mathrm{~cm}^{3}$ of surface sediment were collected to a depth in the sediment of about $10 \mathrm{~cm}$.

The analyses of the sediments consisted of grain size and heavy mineral identification. Grain size was obtained using the sieving method for the sand fraction and the pipette method for the silt-clay fraction, as described by Lewis (1984). Standard textural parameters were calculated using the method of moments. The heavy mineral composition analysis was performed only on the 3.0 phi fraction as recommended by Rendón-Márquez (1995) using sodium polytungstate $\left(3 \mathrm{Na}_{2} \mathrm{WO}_{4}-9 \mathrm{WO}_{3}-\mathrm{H}_{2} \mathrm{O}\right)$ calibrated to a density of $2.85 \mathrm{~g} / \mathrm{cm}^{3}$ as the heavy liquid (Callahan, 1987). The separated minerals were mounted on glass slides with Hystoclad $(\eta=1.54)$ mounting medium for identification using a petrographic microscope, and their relative abundances were recorded. For each sample 200 to 250 grains were counted using the "ribbon" method (Mange and Maurer, 1992). To characterize the spatial distribution 
of the heavy mineral combinations, a principal components analysis (PCA) was applied to heavy mineral abundance data. PCA is a multivariate statistical method that aims at reducing the number of variables. A detailed description of the method is provided in Davis (1986). In this study it was prepared based on a Pearson lineal correlation matrix and its numerical resolution presented, based on the association between the calculated components and the original variables. The results of this characterization were associated to the geology surrounding the bay to locate the sediment sources and/or areas that affect some control over sedimentation, by identifying those components responsible for the mineralogical variability of the deposits (Leinen and Pisias, 1984).

As noted, two models were applied to the sediment grain size data to infer the residual sediment transport by analyzing the spatial trends of the sediment textural properties based on a general four step procedure: 1) the analysis of textural data; 2) the combination of the grain size trends; 3 ) the transport vectors; and 4) the significance statistical test of the transport vectors. Detailed descriptions of the methods are provided in McLaren and Bowles (1985) and in LeRoux (1994a, b).

Semi enclosed basins are influenced by bathymetry and since no detailed bathymetric chart of Bahía Concepción was found in the literature at the time of the investigation, one was prepared based on 18 transects across and parallel to the bay axis obtained with a Raytheon DE-719B echo sounder and positioned with a Magellan NAV5000 DX GPS receiver on board a small Panga type boat. Isobath interval was 1 meter. Detailed bathymetric charts have been published more recently (Rodríguez-Meza et al., 2009; Cheng, et al., 2010).

\section{Results}

Bahía Concepción was found to be a relatively shallow bay. Maximums depths are $38 \mathrm{~m}$ at the southern end and towards the western shore, and $34 \mathrm{~m}$ in the northern part and towards the eastern shore. An interesting feature is the occurrence of a channel along the main axis of the bay that is close to the eastern shore in the northern half, and gradually changes towards the western shore in the southern half. The central portion of the bay is relatively flat, but with the presence of islands and seamounts (Figure 3 ).

Of the 58 samples obtained in Bahía Concepción, 14 were compromised due to improper labeling and storage after the heavy mineral analyses. Therefore grain size was only analyzed on the remaining 44 . The results are shown in Table 1 and in figures 4, 5 and 6. The grain sizes ranged from coarse sand to very fine silt ( 0.84 to $7.64 \mathrm{phi}$ ), their dispersion ranged from moderately to poorly sorted $(0.52$ to $3.17 \mathrm{phi}$ ) and the asymmetry (skewness) values ranged from -0.94 to 1.79 . Typically areas deeper than $20 \mathrm{~m}$ contain the finer sediments. The grain-size analysis data was used to obtain sediment transport trends using the two methods, and the results are shown in figures 7 and 8.

Table 2 shows the proposed transects and their results when a $Z$ test was applied and figure 7 and shows the results of the sediment transport vectors using the McLaren and Bowles (1985) method. This method indicated two main sources of sediment in Bahía Concepción; one located between Playas Santispac and El Coyote (station B1), and the other from Arroyo Cadejé, adjacent to station J1. From this analysis we could also observe the existence of a bidirectional flow of sediments in the bay's mouth; sediment is transported towards the interior of the bay through the central portion of the mouth and to the outside through the margins. Figure 8 shows the results of the sediment transport vectors obtained using the LeRoux (1994a, b) method. The analysis showed the existence of three distinct gyres in the bay; one anticyclonic in the southern portion and two cyclonic in the central portion. It also suggests the existence of a source on the southwest end of the bay, although not as clear as with the McLaren and Bowles (1985) method.

The highest concentrations of total heavy minerals in the bay are present at stations $\mathrm{J} 1, \mathrm{~F} 3$ and $\mathrm{C} 4$, containing 34.0, 29.4 and 29.4\% respectively (Figure 9; Table 3). The arroyos with the highest concentrations of total heavy minerals are Arroyo Cadejé (arr6) and Arroyo Amolares (arr11 and arr12) with 18.4, 23.1 and $18.3 \%$, respectively (Table 4). The lowest concentrations of total heavy minerals $(<4 \%)$ were at the Santispac-Punta Santa Barbara region (stations B1, B2, C0 and C1); north of Playa Requesón (stations E1 and E2); and at the southeastern margin of the bay (stations F6 and G6). Seven principal heavy minerals were identified both in the bay and at the arroyos: biotite, diopside, enstatite, hypersthene, augite, olivine and hornblende (Tables 3 and 4). Augite was the most abundant heavy mineral for all the samples (arroyo bed sediments and marine sediments).

PCA results (Table 5) showed that $64.3 \%$ of the mineral variability in the bay could be explained by three principal components (PC). PC1 explains the behavior of biotite, diopside, enstatite and accounts for $26.1 \%$ of the total variability (Figure 10). PC2 explains the behavior of olivine and augite (Figure 11) and accounts for $22.7 \%$ of the variability. PC3 explains the behavior of hypersthene and hornblende (Figure 12) and accounts for $15.4 \%$ of the variability. The highest values for biotite, enstatite and diopside for PC1 were found on the eastern margin. For PC2, the highest values for olivine were found at Punta Amolares, off Playa Requesón, and at the mouth and head of the bay, and the highest values for augite were found in the proximity of station D6 and Punta Santa Barbara. For PC3 the highest hypersthene values were at the western margin; at Punta Coloradito, Playa Requesón and at the Santa Barbara-Santispac area. Highest hornblende values were found towards the eastern margin. 


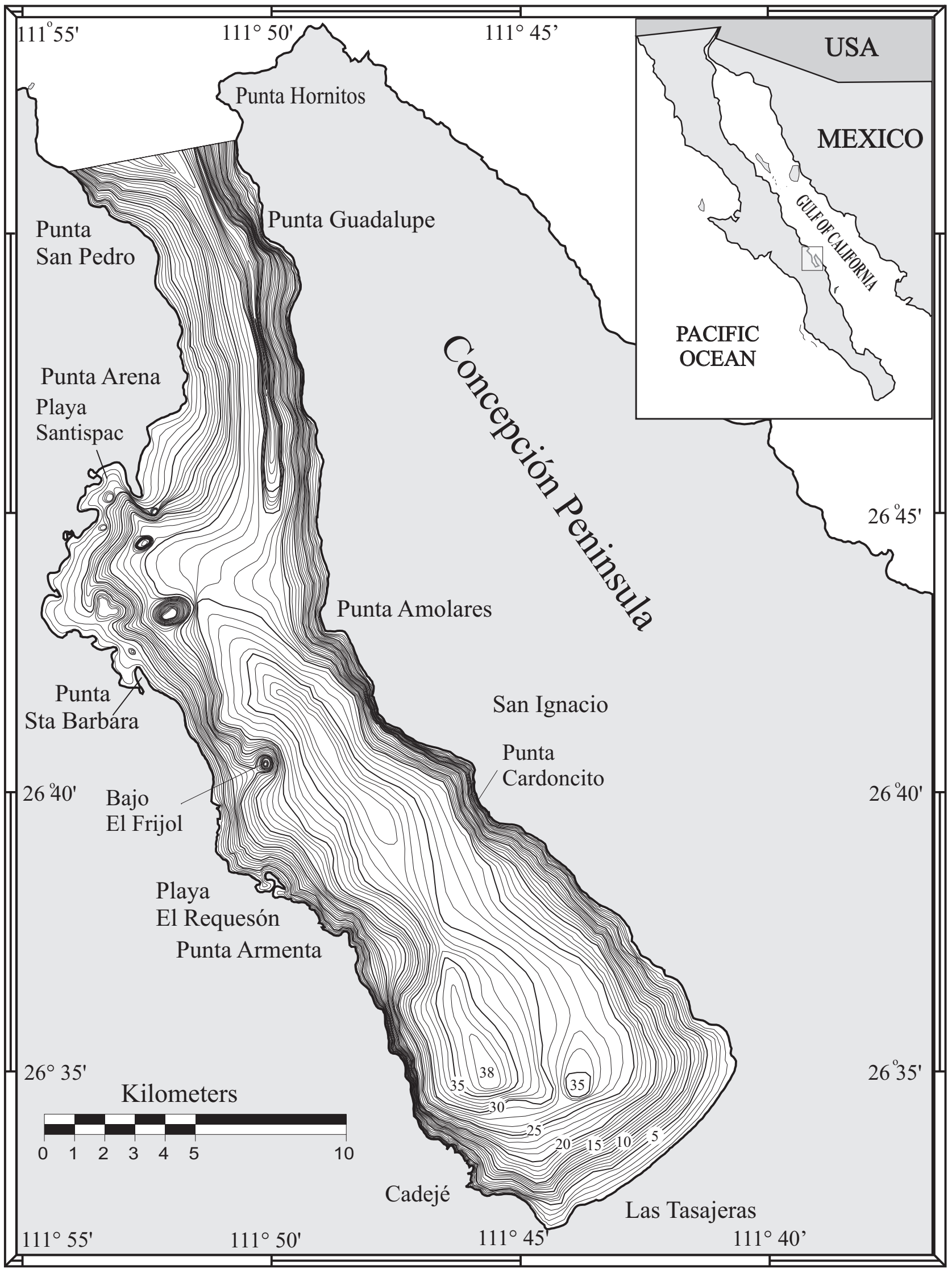

Figure 3. Bathymetry of Bahía Concepción, Baja California Sur, Mexico. Contours in meters 
Table 1. Textural parameters and sediment type for the Bahía Concepción samples.

$\mathrm{MC}=$ mixed carbonate sand (algal and mollusk), $\mathrm{GM}=$ green mud, $\mathrm{VP}=$ volcaniclastic pebbly sand, $\mathrm{GF}=$ Green mud with fine sand and mollusk fragments, VS = volcaniclastic sand with mollusk fragments $\mathrm{CA}=$ calcalgal sand, GS = green mud with whole mollusk shells.

\begin{tabular}{|c|c|c|c|c|c|}
\hline Station & Sediment type & Depth (m) & Mean (phi) & Sorting (phi) & Sk (phi) \\
\hline $\mathrm{A} 1$ & $\mathrm{MC}$ & 4.9 & 0.85 & 1.04 & 0.39 \\
\hline A2 & GM & 20 & 6.69 & 1.53 & -0.05 \\
\hline A4 & GM & 25 & 2.81 & 1.02 & -0.93 \\
\hline A5 & VP & 4.5 & 0.84 & 0.79 & 0.31 \\
\hline B1 & GF & 16.5 & 2.92 & 2.98 & 0.82 \\
\hline B2 & GM & 20 & 6.42 & 1.67 & 1.41 \\
\hline B3 & GM & 24 & 6.84 & 1.52 & -0.76 \\
\hline B5 & VS & 19 & 2.03 & 1.02 & -0.95 \\
\hline B6 & VP & 4 & 2.13 & 0.99 & -0.81 \\
\hline $\mathrm{C} 0$ & $\mathrm{MC}$ & 12 & 1.07 & 1.11 & 0.41 \\
\hline $\mathrm{C} 2$ & GM & 20 & 6.56 & 1.13 & -0.23 \\
\hline $\mathrm{C} 3$ & GM & 25 & 7.65 & 1.66 & -0.38 \\
\hline $\mathrm{C} 5$ & VS & 2 & 1.05 & 1.13 & 0.32 \\
\hline D1 & GF & 21 & 1.27 & 1.48 & 0.6 \\
\hline $\mathrm{D} 2$ & GF & 25 & 1.79 & 1.3 & -0.02 \\
\hline D5 & VS & 6.5 & 1.2 & 1.11 & 0.23 \\
\hline D6 & VS & 1.5 & 1.92 & 0.79 & 0.47 \\
\hline E1 & $\mathrm{CA}$ & 10 & 1.33 & 0.99 & -0.05 \\
\hline E2 & GS & 24 & 4.07 & 3.17 & 0.51 \\
\hline E4 & GM & 28 & 6.84 & 1.41 & 0.2 \\
\hline E6 & VS & 15 & 1.39 & 1.07 & 0.15 \\
\hline F1 & $\mathrm{CA}$ & 14 & 1.07 & 0.95 & 0.36 \\
\hline F2 & GM & 24 & 6.43 & 1.37 & 0.52 \\
\hline F4 & GM & 25 & 7.21 & 1.45 & -0.64 \\
\hline F6 & VS & 16 & 2.34 & 0.95 & -0.44 \\
\hline G1 & GM & 25 & 5.23 & 1.43 & 0.83 \\
\hline G3 & GM & 33 & 7.21 & 1.41 & -0.55 \\
\hline G6 & VS & 19 & 1.73 & 1.24 & 0.13 \\
\hline H1 & GM & 24 & 5.38 & 1.53 & 0.12 \\
\hline H3 & GS & 31 & 5.96 & 1.34 & 0.68 \\
\hline H4 & GM & 23 & 5.79 & 1.19 & 0.95 \\
\hline H6 & GM & 18 & 3.09 & 2.49 & 0.26 \\
\hline I1 & GF & 28 & 1.42 & 1.36 & 0.59 \\
\hline I2 & GM & 30 & 6.57 & 1.64 & 0 \\
\hline $\mathrm{J} 1$ & GF & 24 & 2.19 & 1.52 & -0.04 \\
\hline M1 & VS & 6 & 2.79 & 1.21 & -0.69 \\
\hline M3 & GM & 20 & 6.11 & 2.16 & -0.15 \\
\hline M4 & VP & 3.5 & 0.95 & 1.09 & 1.79 \\
\hline N1 & VS & 2.5 & 2.41 & 0.52 & -0.23 \\
\hline N2 & GF & 21 & 1.56 & 1.29 & 0.09 \\
\hline N3 & VS & 18 & 1.08 & 1.08 & 0.33 \\
\hline $\mathrm{O} 1$ & VP & 3 & 1.28 & 1.07 & 0.21 \\
\hline $\mathrm{O} 2$ & VS & 17 & 2.21 & 0.9 & 0.26 \\
\hline $\mathrm{O} 3$ & GM & 34 & 2.97 & 1.08 & -0.92 \\
\hline
\end{tabular}




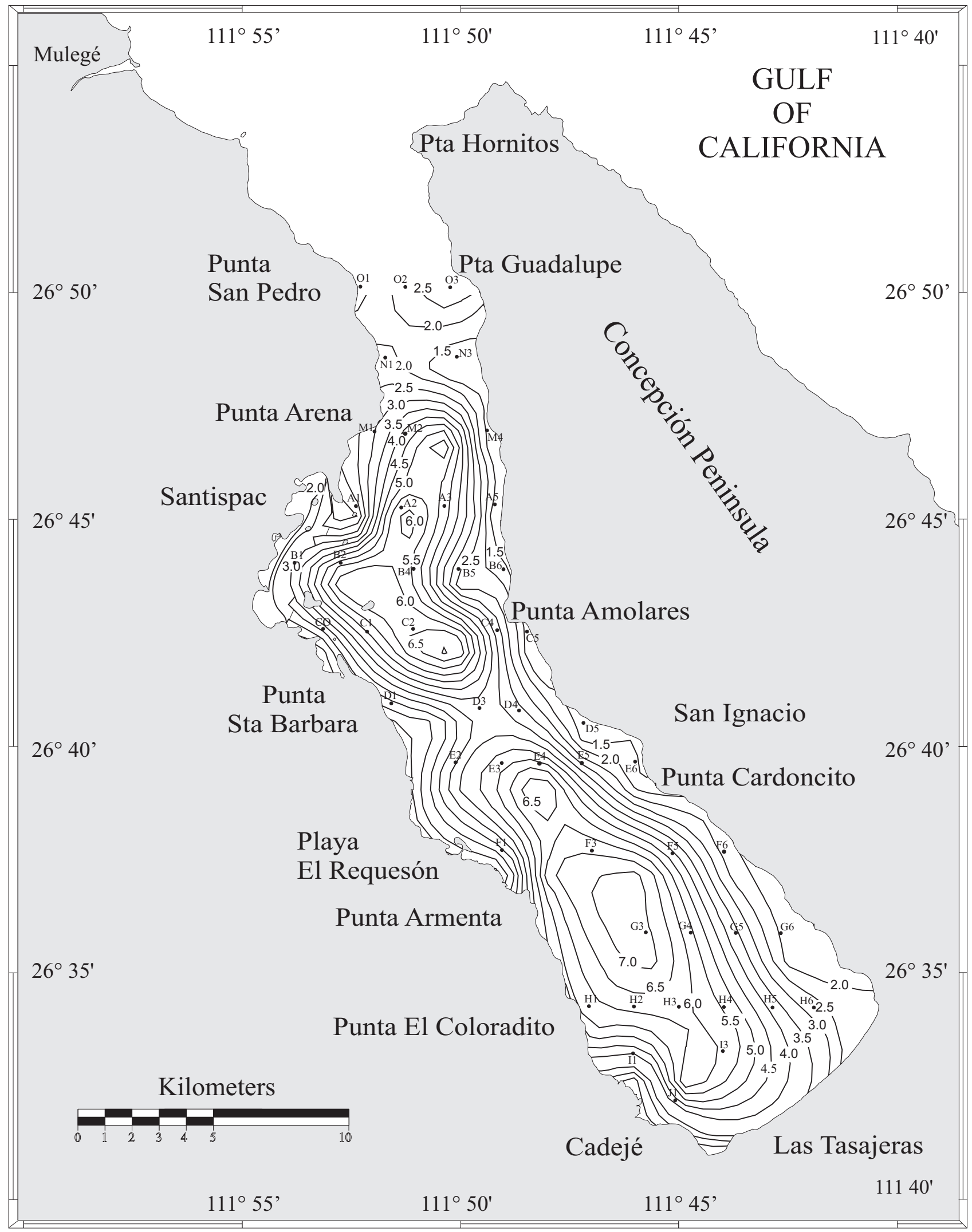

Figure 4. Mean grain size distribution (phi units) of surface sediments in Bahía Concepción, Baja California Sur, Mexico. 


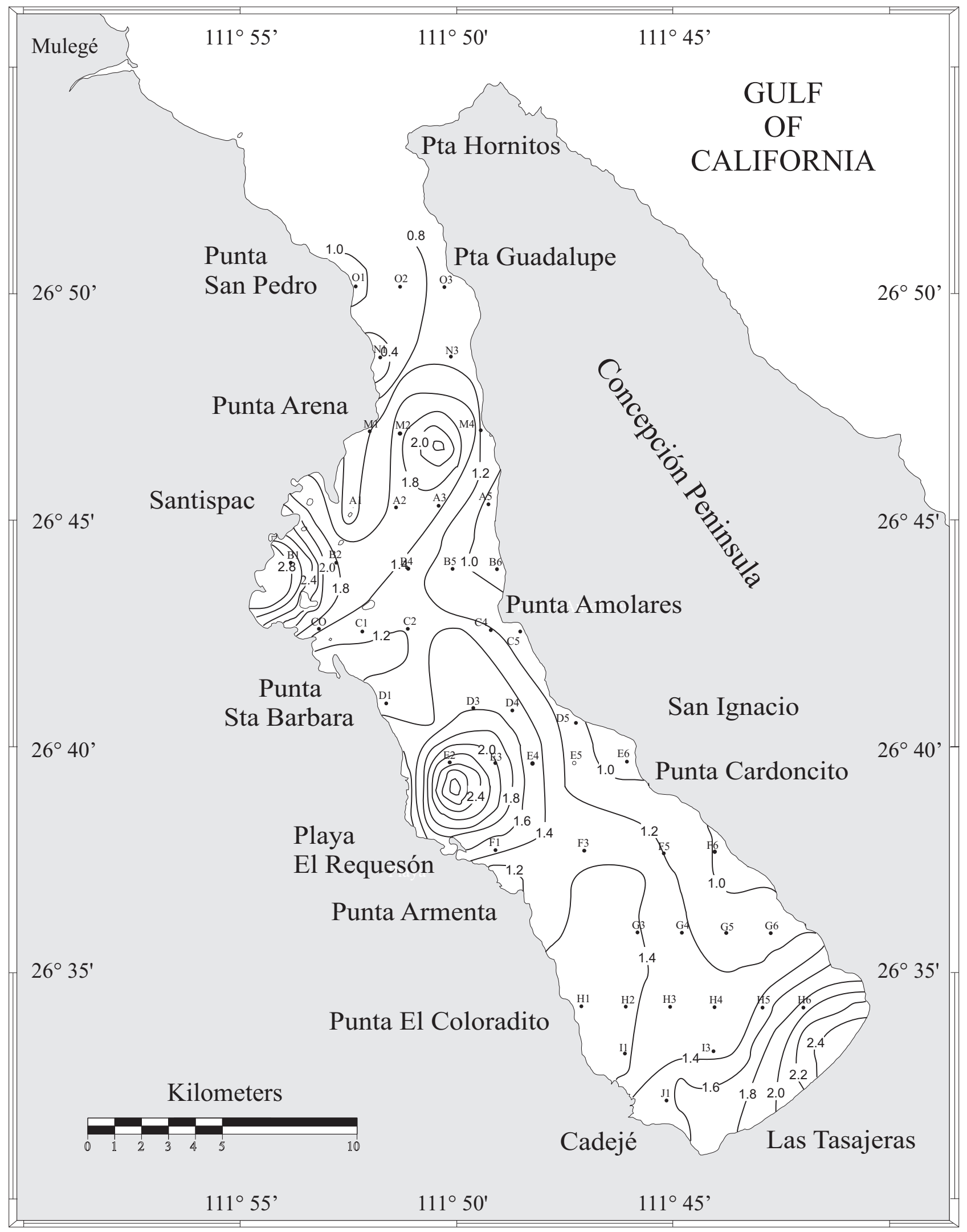

Figure 5. Sorting distribution (phi units) of surface sediments in Bahía Concepción, Baja California Sur, Mexico. 


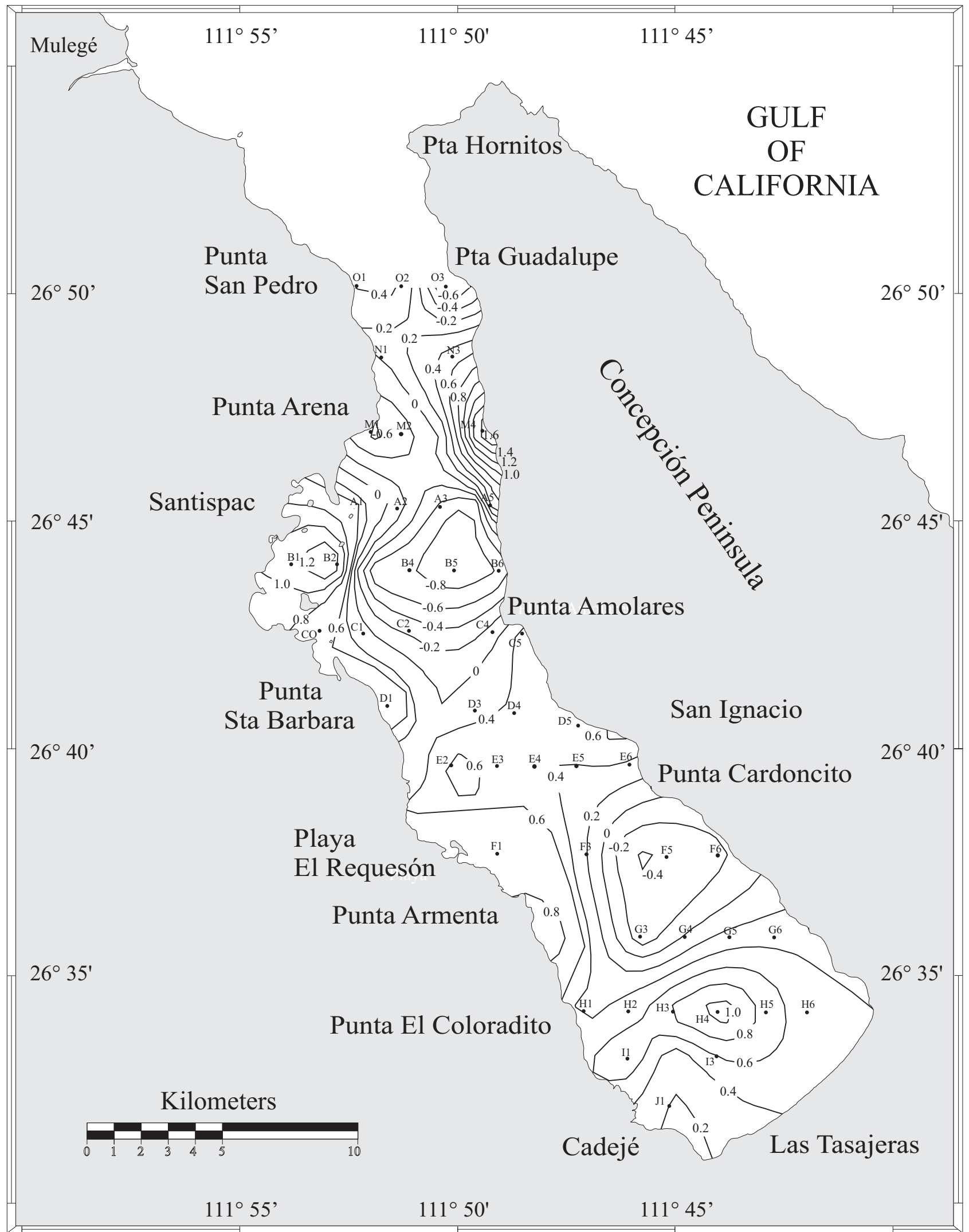

Figure 6. Asymmetry distribution (phi units) of surface sediments in Bahía Concepción, Baja California Sur, Mexico. 


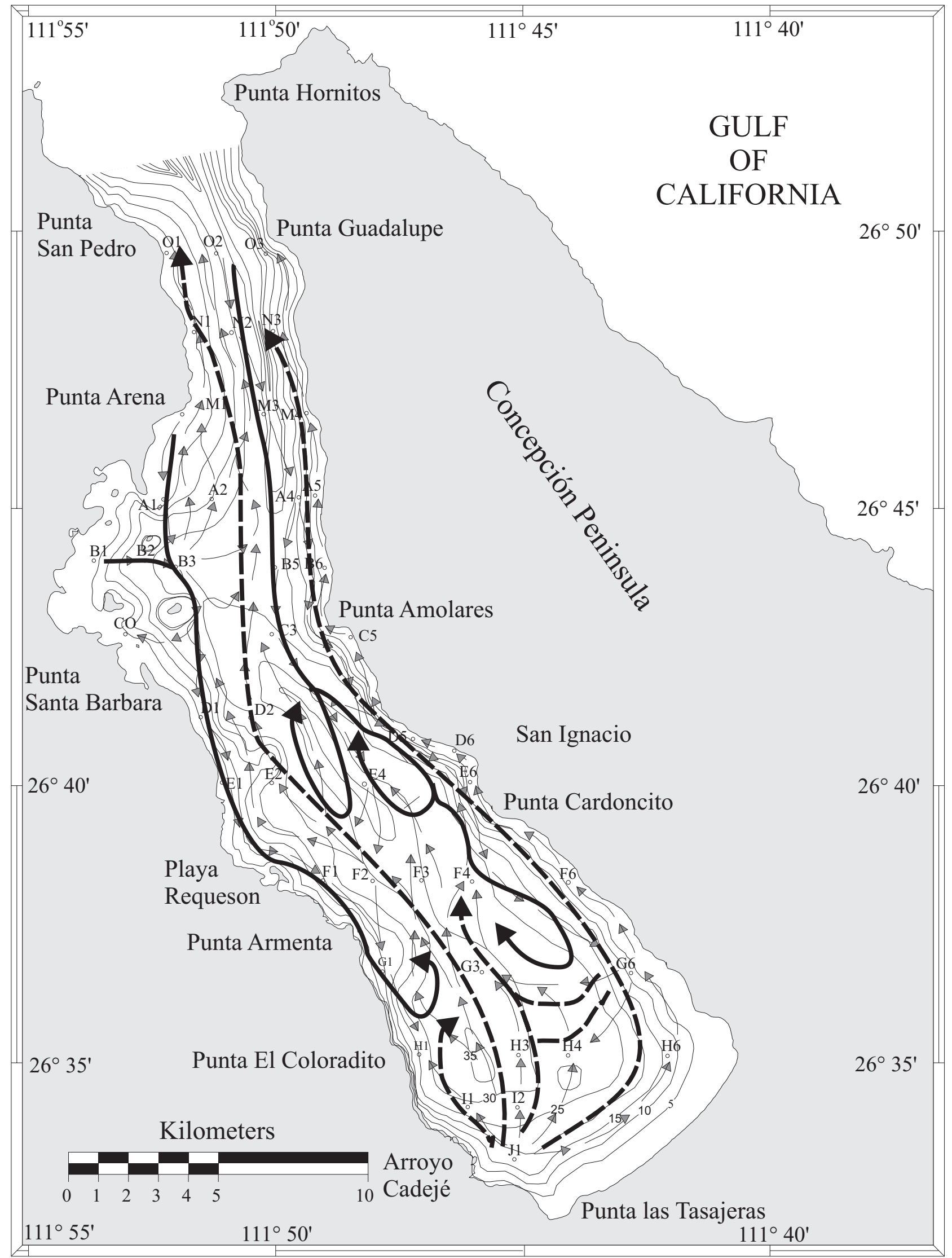

Figure 7. Results of the sediment transport vectors using the McLaren and Bowles (1985) method. 


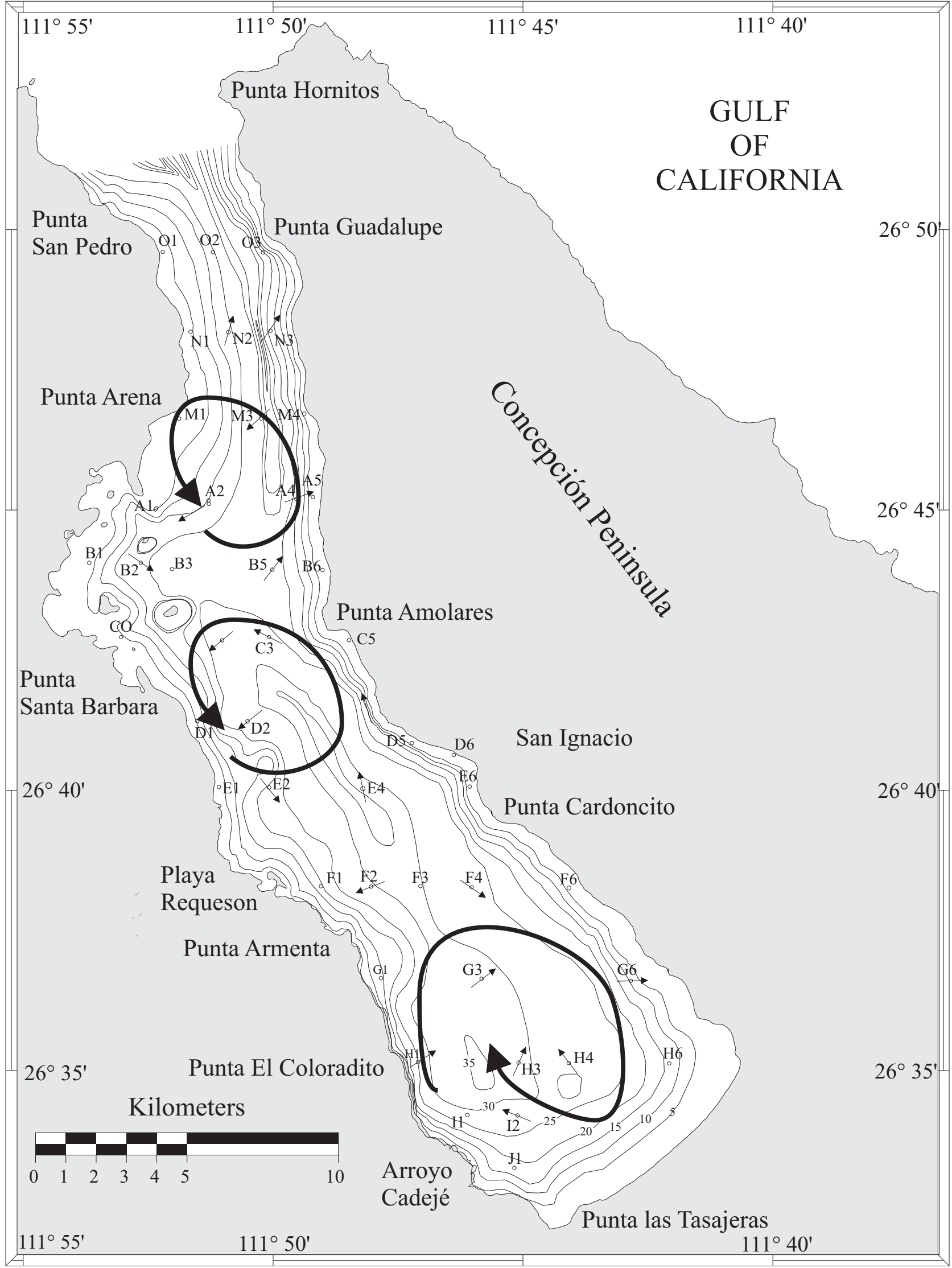

Figure 8. Results of the sediment transport vectors using the LeRoux (1994a, b) method. 
Table 2. Proposed transects for the McLaren and Bowles (1985) method and their transport trend result after applying a Z statistic at $90 \%$ significance. $\mathrm{N}$ denotes a northward trend; $\mathrm{S}$ indicates southward trend; NT indicates no trend; A indicates transects that show ambiguity.

\begin{tabular}{|c|c|c|c|c|c|c|c|c|c|c|c|c|c|c|c|c|c|c|}
\hline \multicolumn{19}{|c|}{ Transects } \\
\hline 1 & 2 & 3 & 4 & 5 & 6 & 7 & 8 & 9 & 10 & 11 & 12 & 13 & 14 & 15 & 16 & 17 & 18 & 19 \\
\hline $\mathrm{O} 3$ & B6 & $\mathrm{C} 0$ & $\mathrm{O} 2$ & O1 & N1 & M1 & A1 & B3 & E1 & M3 & $\mathrm{O} 1$ & $\mathrm{O} 3$ & $\mathrm{O} 3$ & D2 & D1 & B6 & $\mathrm{C} 2$ & $\mathrm{O} 2$ \\
\hline N3 & $\mathrm{C} 5$ & D1 & $\mathrm{N} 2$ & N1 & M1 & A1 & B3 & $\mathrm{C} 2$ & E2 & A4 & N1 & $\mathrm{N} 3$ & N3 & E1 & D2 & $\mathrm{C} 5$ & D2 & $\mathrm{N} 2$ \\
\hline M4 & D5 & E1 & M3 & M1 & A1 & B3 & $\mathrm{C} 2$ & E4 & E4 & B5 & M1 & M4 & M4 & F1 & E4 & D5 & E1 & M3 \\
\hline A5 & D6 & F1 & A4 & A1 & B3 & $\mathrm{C} 2$ & E4 & F4 & F4 & $\mathrm{C} 3$ & $\mathrm{~A} 2$ & A4 & A4 & G1 & F4 & D6 & $\mathrm{F} 1$ & M1 \\
\hline B6 & E6 & G1 & B5 & B3 & $\mathrm{C} 2$ & E4 & F4 & G3 & G3 & D2 & B3 & A2 & A2 & H1 & G3 & E6 & F2 & A2 \\
\hline C5 & F6 & H1 & $\mathrm{C} 3$ & $\mathrm{C} 2$ & E4 & $\mathrm{F} 4$ & G3 & H3 & H3 & E2 & $\mathrm{C} 2$ & B3 & A1 & H3 & H3 & $\mathrm{F} 4$ & G3 & A1 \\
\hline D5 & G6 & I1 & D2 & E4 & $\mathrm{F} 4$ & G3 & $\mathrm{H} 3$ & I2 & $\mathrm{I} 2$ & $\mathrm{~F} 2$ & D5 & B2 & B2 & $\mathrm{H} 4$ & $\mathrm{I} 2$ & G1 & G6 & B2 \\
\hline D6 & H6 & $\mathrm{J} 1$ & E1 & $\mathrm{F} 4$ & G3 & $\mathrm{H} 3$ & $\mathrm{I} 2$ & $\mathrm{~J} 1$ & $\mathrm{~J} 1$ & G1 & D6 & $\mathrm{B} 1$ & B1 & H6 & $\mathrm{J} 1$ & $\mathrm{H} 1$ & H6 & $\mathrm{B} 1$ \\
\hline $\mathbf{N}$ & NT & $\mathbf{N}$ & NT & $\mathbf{N}$ & $\mathbf{N}$ & $\mathbf{A}$ & $\mathbf{N}$ & $\mathbf{A}$ & NT & NT & $\mathbf{A}$ & $\mathbf{N}$ & $\mathbf{N}$ & NT & $\mathbf{N}$ & $\mathbf{N}$ & $\mathbf{N}$ & NT \\
\hline \multicolumn{19}{|c|}{ Transects } \\
\hline 20 & 21 & 22 & 23 & 24 & 25 & 26 & 27 & 28 & 29 & 30 & 31 & 32 & 33 & 34 & 35 & 36 & 37 & 38 \\
\hline $\mathrm{O} 2$ & $\mathrm{O} 2$ & $\mathrm{C} 5$ & A4 & A4 & M1 & $\mathrm{C} 0$ & D6 & B1 & B1 & M1 & A4 & $\mathrm{N} 2$ & B5 & M1 & A4 & B5 & M1 & A1 \\
\hline $\mathrm{N} 2$ & N2 & D5 & B5 & B5 & A2 & D2 & D5 & $\mathrm{C} 0$ & B2 & A1 & B5 & M3 & C3 & A1 & B5 & C3 & Al & B1 \\
\hline M3 & M3 & D6 & C3 & $\mathrm{C} 3$ & $\mathrm{C} 2$ & E2 & C5 & D2 & B3 & B3 & $\mathrm{C} 2$ & A4 & D5 & B3 & $\mathrm{C} 3$ & D5 & B1 & $\mathrm{C} 0$ \\
\hline A2 & A4 & E6 & E4 & E4 & D2 & $\mathrm{F} 2$ & B6 & E4 & $\mathrm{C} 2$ & D1 & E4 & B5 & D6 & D1 & E4 & D6 & $\mathrm{C} 0$ & D1 \\
\hline B5 & B5 & F6 & $\mathrm{F} 4$ & $\mathrm{~F} 4$ & E2 & G3 & A4 & F4 & E4 & E1 & F4 & C3 & E6 & E1 & $\mathrm{F} 2$ & E6 & D1 & E1 \\
\hline C3 & $\mathrm{C} 3$ & G6 & H4 & G3 & F2 & H3 & M3 & G3 & $\mathrm{F} 2$ & F1 & G3 & E4 & F4 & $\mathrm{F} 1$ & G1 & F4 & E1 & $\mathrm{F} 1$ \\
\hline E4 & E4 & H6 & I2 & $\mathrm{H} 4$ & $\mathrm{I} 2$ & $\mathrm{I} 2$ & N2 & $\mathrm{H} 4$ & G1 & G1 & H3 & F4 & G6 & G1 & H1 & G3 & $\mathrm{F} 1$ & G1 \\
\hline F4 & F1 & $\mathrm{J} 1$ & $\mathrm{~J} 1$ & H6 & $\mathrm{J} 1$ & $\mathrm{~J} 1$ & $\mathrm{O} 2$ & $\mathrm{~J} 1$ & H1 & H1 & $\mathrm{J} 1$ & H6 & $\mathrm{H} 4$ & H3 & I2 & H6 & G1 & H1 \\
\hline $\mathbf{N}$ & $\mathbf{S}$ & $\mathbf{N}$ & NT & NT & $\mathbf{N}$ & $\mathbf{N}$ & $\mathbf{S}$ & $\mathbf{N}$ & $\mathbf{S}$ & $\mathbf{S}$ & NT & NT & $\mathbf{S}$ & $\mathbf{S}$ & NT & $\mathbf{N}$ & NT & NT \\
\hline
\end{tabular}

\section{Discussion}

\subsection{Sediment Transport}

The bi-directional pattern of sediment transport near the entrance of the bay obtained with the McLaren and Bowles (1985) method, in which sediment tends to be exported from the shallow areas and enters the bay through the deeper channel (Figure 7), is most likely the result of ebb and flood tidal currents since, as in most coastal bays, the mouth is the pathway for the exchange of water from the ocean to the bay and vice versa. It is through this pathway that the tidal prism must pass during the tidal cycles, generating strong currents and entraining sediment (Price, 1963). This idea is supported by the findings of Ponte et al. (2006); they observed vertically stratified circulation driven by wind and tides using fixed-depth drifters (surface, $10 \mathrm{~m}$ and 20 $\mathrm{m}$ deep) deployed during January and March of 2005 on a transect $5 \mathrm{~km}$ south of the entrance of the bay. They found that at the surface, 10 out of 12 drifters went south. At a depth of $10 \mathrm{~m}$, the drifters oscillated around their release positions and along the axis of the channel while being slowly advected to the south. At $20 \mathrm{~m}$, all drifters oscillated in the same way but where advected to the north, out of the bay. For the rest of the bay, the McLaren and Bowles (1985) method showed a general transport direction to the north on the eastern margin, and to the south on most of the western margin. This is also supported by the findings of Ponte et al. (2006). They observed that from a south transect (20 km south of the entrance) drifters deployed at the same horizontal position but different depths follow similar trajectories: a cyclonic pattern around the end of the bay. They observed that throughout the water column, velocities are toward the end of the bay on the western side and toward the entrance on the eastern side of the bay. The exception to this pattern is the area just north of station $\mathrm{J} 1$, where the current velocities are weak and the steeper slopes (Figure 3) most likely control the direction of the sediment transport toward the north and deeper parts of the bay.

The gyres obtained with the LeRoux (1994a, b) method (Figure 8) for the central part of the bay can be attributed to both a tidal effect and wind induced flow. The bay is a narrow and shallow body of water and the tides generate currents that converge in the central part of the bay (Obeso Nieblas et al., 1996; Gutierrez de Velasco et al., 2006; Ponte et al., 2006). The proposed pattern is supported by the observations of Valle-Levinson et al. (2006) who found that the spatial structure of the wind-induced flow in the bay 


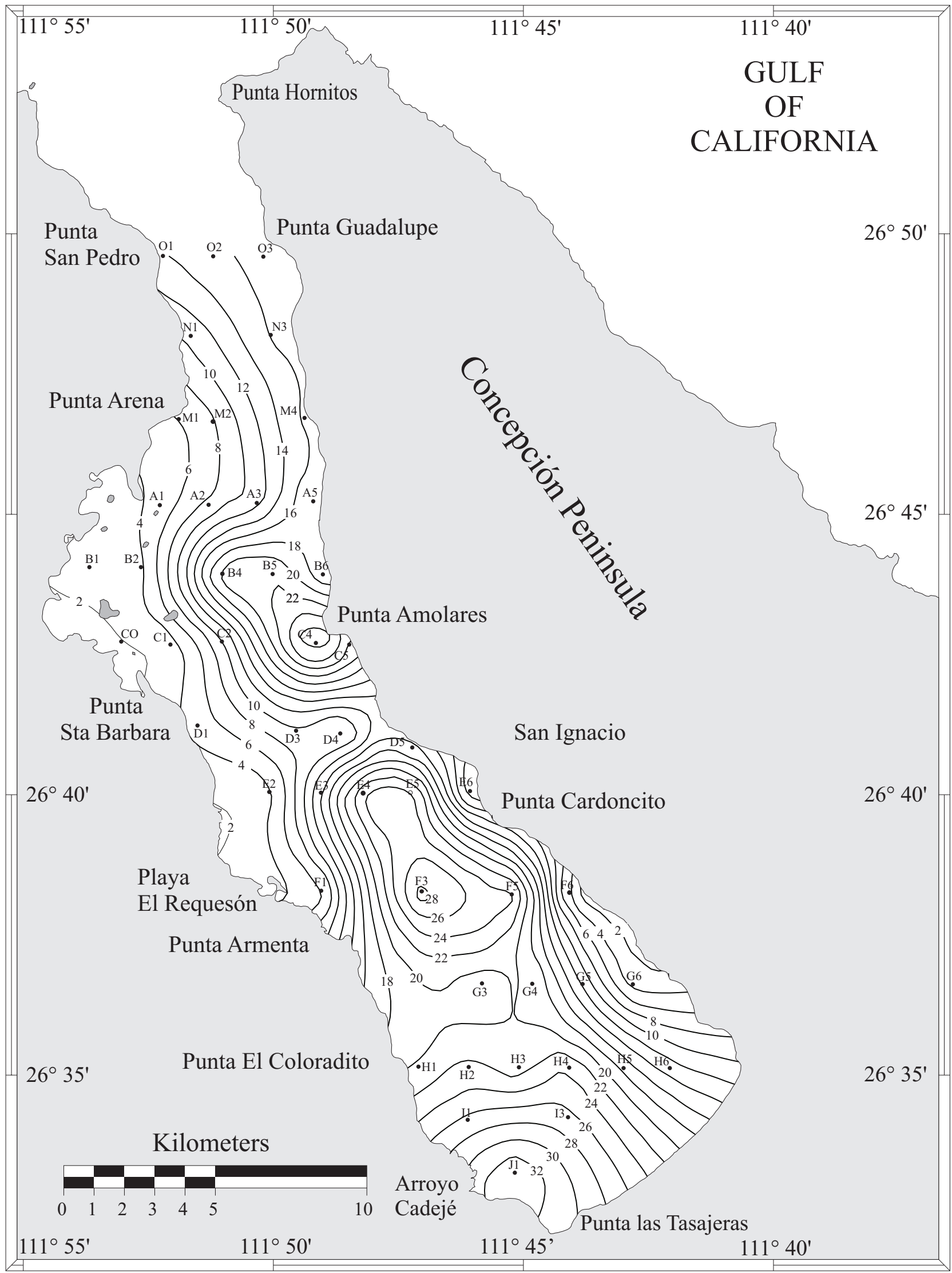

Figure 9. Percentage of total heavy mineral content in Bahía Concepción. Maximum values correspond to sampling stations J1 (34\%), F3 (29.4\%) and C4 (29.4\%). 
Table 3. Relative abundance (Wt. percent) of total heavy mineral fraction and of individual minerals identified in the 3 phi fraction of the sediment samples.

\begin{tabular}{|c|c|c|c|c|c|c|c|c|}
\hline Station & $\begin{array}{c}\text { Heavy } \\
\text { minerals }\end{array}$ & biotite & diopside & enstatite & hypersthene & augite & olivine & hornblende \\
\hline A1 & 4.6 & 10.6 & 4.3 & 4.3 & 25.5 & 42.6 & 4.3 & 8.5 \\
\hline A2 & 8.4 & 5.1 & 2.6 & 2.6 & 5.1 & 43.6 & 12.8 & 28.2 \\
\hline $\mathbf{A 3}$ & 10.8 & 5.2 & 5.2 & 1.7 & 27.6 & 43.1 & 6.9 & 10.3 \\
\hline A4 & 16.2 & 15.6 & 7.3 & 8.3 & 5.2 & 33.3 & 14.6 & 15.6 \\
\hline A5 & 18.1 & 18 & 7.2 & 7.2 & 4.5 & 31.5 & 15.3 & 16.2 \\
\hline B1 & 2.9 & 3.8 & 5.7 & 5.7 & 26.4 & 47.2 & 1.9 & 9.4 \\
\hline B2 & 2.5 & 2.3 & 4.7 & 7 & 18.6 & 51.2 & 7 & 9.3 \\
\hline B3 & 27.3 & 16.2 & 2.7 & 2.7 & 16.2 & 46 & 2.7 & 13.5 \\
\hline B4 & 22.2 & 8.6 & 1.7 & 3.5 & 10.3 & 50 & 8.6 & 17.3 \\
\hline B5 & 22.2 & 5.5 & 3.6 & 3.6 & 5.5 & 54.6 & 10.9 & 16.4 \\
\hline B6 & 16.1 & 16.1 & 8.6 & 7.5 & 4.3 & 41.9 & 10.8 & 10.8 \\
\hline $\mathrm{CO}$ & 2 & 1.8 & 3.6 & 3.6 & 28.6 & 55.4 & 3.6 & 3.6 \\
\hline $\mathrm{C} 1$ & 2.5 & 8.5 & 2.1 & 2.1 & 17 & 59.6 & 4.3 & 6.4 \\
\hline $\mathrm{C} 2$ & 8.9 & 14 & 3.5 & 1.8 & 19.3 & 40.4 & 5.3 & 15.8 \\
\hline C3 & 22 & 12.1 & 6.1 & 6.1 & 3 & 33.3 & 9.1 & 30.3 \\
\hline $\mathrm{C} 4$ & 29.4 & 31.3 & 7.1 & 8.1 & 1 & 33.3 & 11.1 & 8.1 \\
\hline $\mathrm{C} 5$ & 22.2 & 17.2 & 9.9 & 8.6 & 1.2 & 42 & 11.1 & 9.9 \\
\hline D1 & 5 & 6.1 & 6.1 & 2 & 20.4 & 57.1 & 4.1 & 4.1 \\
\hline D2 & 8.4 & 1.8 & 5.4 & 7.1 & 10.7 & 41.1 & 3.3 & 30.4 \\
\hline D3 & 9.6 & 4.8 & 4.8 & 7.1 & 11.9 & 47.6 & 2.4 & 21.4 \\
\hline D4 & 6.2 & 7.5 & 5 & 10 & 12.5 & 50 & 10 & 5 \\
\hline D5 & 14 & 14.7 & 8.8 & 11.8 & 4.4 & 48.5 & 1.5 & 10.3 \\
\hline D6 & 12 & 12.7 & 11.1 & 4.8 & 1.6 & 55.6 & 1.6 & 12.7 \\
\hline E1 & 2.1 & 8.9 & 8.9 & 2.2 & 22.2 & 48.9 & 2.2 & 6.7 \\
\hline E2 & 2.8 & 3 & 3 & 6.1 & 30.3 & 27.3 & 9.1 & 21.2 \\
\hline E3 & 13.9 & 2.8 & 5.6 & 5.6 & 22.2 & 30.6 & 5.6 & 27.8 \\
\hline E4 & 24.7 & 4.2 & 8.3 & 4.2 & 12.5 & 58.3 & 4.2 & 8.3 \\
\hline E5 & 26 & 17.5 & 11.1 & 4.8 & 4.8 & 46 & 3.2 & 12.7 \\
\hline E6 & 5.8 & 20.3 & 10.8 & 4.1 & 4.1 & 44.6 & 2.7 & 13.5 \\
\hline F1 & 4.7 & 9.1 & 3.6 & 1.8 & 25.5 & 47.3 & 3.6 & 9.1 \\
\hline F2 & 20 & 5.8 & 1.9 & 1.9 & 11.5 & 50 & 3.9 & 25 \\
\hline F3 & 29.4 & 4.4 & 4.4 & 2.2 & 2.2 & 53.3 & 2.2 & 31.1 \\
\hline F4 & 27.8 & 11.8 & 5.9 & 5.9 & 11.8 & 41.2 & 5.9 & 17.7 \\
\hline F5 & 24.1 & 14.6 & 9.1 & 7.3 & 1.8 & 49.1 & 7.3 & 10.9 \\
\hline F6 & 2.1 & 11.1 & 11.1 & 7.9 & 1.6 & 47.6 & 7.9 & 12.7 \\
\hline G3 & 18.4 & 5 & 7.5 & 5 & 15 & 35 & 10 & 22.5 \\
\hline G4 & 20.5 & 2.3 & 2.3 & 7 & 9.3 & 55.8 & 9.3 & 14 \\
\hline G5 & 11.8 & 8.3 & 1.7 & 6.7 & 5 & 43.3 & 11.7 & 23.3 \\
\hline G6 & 2.8 & 3.2 & 12.9 & 6.5 & 6.5 & 41.9 & 11.3 & 17.7 \\
\hline H1 & 20.1 & 13.6 & 8.5 & 1.7 & 32.2 & 33.9 & 5.1 & 5.1 \\
\hline H2 & 22.6 & 2.9 & 5.7 & 2.9 & 5.7 & 34.3 & 17.1 & 31.4 \\
\hline H3 & 20.3 & 6.7 & 1.7 & 1.7 & 16.7 & 45 & 11.7 & 16.7 \\
\hline H4 & 24.4 & 12.1 & 3 & 1.5 & 6.1 & 40.9 & 12.1 & 24.2 \\
\hline H5 & 17.9 & 5.3 & 5.3 & 5.3 & 2.6 & 39.5 & 21.1 & 21.1 \\
\hline H6 & 12.9 & 21.7 & 8.4 & 2.4 & 1.2 & 47 & 9.6 & 9.6 \\
\hline I1 & 26.4 & 16.3 & 8.2 & 3.1 & 8.2 & 40.8 & 18.4 & 5.1 \\
\hline I3 & 26.9 & 4.8 & 4.8 & 3.2 & 11.1 & 44.4 & 17.5 & 14.3 \\
\hline J1 & 34 & 13.6 & 9.1 & 5.5 & 8.2 & 39.1 & 14.6 & 10 \\
\hline M1 & 5.9 & 1.8 & 3.5 & 8.8 & 26.3 & 31.6 & 17.5 & 10.5 \\
\hline M2 & 7.6 & 12.5 & 2.5 & 5 & 10 & 37.5 & 12.5 & 20 \\
\hline M3 & 12.2 & 2.1 & 6.4 & 6.4 & 6.4 & 46.8 & 6.4 & 25.5 \\
\hline M4 & 16.3 & 18.5 & 8.9 & 8.2 & 5.9 & 29.6 & 14.2 & 14.8 \\
\hline N1 & 10.4 & 3.3 & 1.7 & 8.3 & 33.3 & 21.7 & 16.7 & 15 \\
\hline N2 & 13 & 10.5 & 5.3 & 5.3 & 13.2 & 29 & 7.9 & 29 \\
\hline N3 & 16.3 & 21.1 & 10.1 & 9.2 & 5.5 & 26.6 & 12.8 & 14.7 \\
\hline 01 & 13.8 & 2.2 & 2.2 & 6.5 & 32.6 & 21.7 & 17.4 & 17.4 \\
\hline $\mathrm{O} 2$ & 15.5 & 26.8 & 4.9 & 7.3 & 26.8 & 19.5 & 4.9 & 9.8 \\
\hline $\mathbf{O 3}$ & 16.7 & 19.5 & 5.2 & 3.9 & 15.6 & 32.5 & 6.5 & 16.9 \\
\hline
\end{tabular}


Table 4. Relative abundance (Wt. percent) of total heavy mineral fraction and of individual minerals identified in the 3 phi fraction of the arroyo sediment samples.

\begin{tabular}{lcccccccc}
\hline \multicolumn{1}{c}{ Arroyo } & minerals & biotite & diopside & enstatite & hyperesthene & augite & olivine & hornblende \\
\hline Arr1 & 8.4 & 3.6 & 3.1 & 5.6 & 25.6 & 28.3 & 18.3 & 15.6 \\
Arr2 & 9.2 & 25.5 & 4.7 & 5.6 & 21.4 & 28.4 & 4.2 & 10.3 \\
Arr3 & 8.7 & 2.2 & 4.6 & 4.2 & 19.8 & 58.4 & 5.6 & 5.2 \\
Arr4 & 4.5 & 4.5 & 3.6 & 8.5 & 22.3 & 32.4 & 11.3 & 17.6 \\
Arr5 & 8.3 & 12.1 & 3.1 & 3.5 & 21 & 45.2 & 4.6 & 10.5 \\
Arr6 & 18.4 & 10.7 & 9.6 & 6.2 & 9 & 37 & 18.9 & 8.6 \\
Arr7 & 10.1 & 11.2 & 9.3 & 4.2 & 2.5 & 48.4 & 13.4 & 11 \\
Arr8 & 10.3 & 14.3 & 9.5 & 3.1 & 2.1 & 50.6 & 10.2 & 10.1 \\
Arr9 & 3.4 & 10.2 & 15.6 & 6.7 & 3.2 & 45.5 & 7.4 & 11.5 \\
Arr10 & 12 & 5.7 & 8.2 & 10.3 & 5.2 & 55.8 & 4.3 & 10.5 \\
Arr11 & 23.1 & 10.3 & 8.6 & 9.1 & 2.4 & 45.3 & 14.6 & 9.9 \\
Arr12 & 18.3 & 18.2 & 8.9 & 7.6 & 5.2 & 39.6 & 10.3 & 10.2 \\
Arr13 & 12.1 & 14.3 & 6.5 & 4.2 & 13.5 & 36.6 & 7.1 & 17.9 \\
\hline
\end{tabular}

Table 5. Summarized results of the principal component analysis. The upper panel shows the eigenanalysis of the PCA. The lower panel shows the correlation coefficients between the calculated components and the original variables.

\begin{tabular}{lrrr}
\hline Eigenvalue & 1.8293 & 1.5118 & 1.0792 \\
Proportion & 0.261 & 0.227 & 0.154 \\
Cumulative & 0.261 & 0.489 & 0.643 \\
\hline & $\mathbf{P C 1}$ & $\mathbf{P C 2}$ & $\mathbf{P C 3}$ \\
Biotite & $\mathbf{0 . 5 8 8}$ & 0.056 & 0.163 \\
Diopside & $\mathbf{0 . 5 9 8}$ & 0.222 & -0.012 \\
Enstatite & $\mathbf{0 . 4 0 2}$ & -0.305 & 0.294 \\
Hypersthene & -0.297 & -0.143 & $\mathbf{0 . 7 5 4}$ \\
Augite & 0.038 & $\mathbf{0 . 5 1 7}$ & -0.122 \\
Olivine & 0.209 & $\mathbf{- 0 . 5 8 4}$ & 0.013 \\
Hornblende & -0.034 & -0.475 & $\mathbf{- 0 . 5 5 1}$ \\
\hline
\end{tabular}

depicted a cyclonic gyre that featured downwind flow on the western side of the bay (to the right looking downwind) and upwind flow on the eastern side.

Tidal currents decrease toward the southern portion of the bay, becoming very weak toward the head (Obeso Nieblas et al., 1996; Ponte et al., 2006) and the sediment most likely is not entrained by tidal currents as the main transport agent. Ponte et al. (2006) found that at $20 \mathrm{~m}$ depth, drifters liberated from the middle of the bay started a cyclonic motion near the head of the bay, but did not complete a loop pattern as their velocities weakened. The southern end of the bay behaves in a consistent manner with observations of the wind-wave patterns. Winds are commonly from the northwest during the fall and winter and from the southeast during the spring and summer. The northwesterly winds are stronger and more persistent and generate a littoral current on the western margin to the south and east in the southern end (Gutierrez de Velasco et al., 2006). This pattern of wave energy generates suspension of sediments in the nearshore zone, preventing settling and providing sediment to be carried by the gyre to a depocenter. This depocenter is most likely located at or near stations F2 and F3, since both of the textural models applied show that trends converge near station F3, midpoint between Playa Requesón and Punta Cardoncito. The existence and location of this depocenter is also evident in the results for the McLaren and Bowles (1985) method; the northerly and southerly trajectories on the west margin converge at Punta Coloradito and move towards the depths of the bay and around station F3. Other trajectories radiating to the north from Arroyo Cadejé also move towards F3.

Two main sources of sediment were identified for the bay; the area adjacent to Cadejé Basin and the area between Playa Santispac and El Coyote. The existence of the Cadejé main sediment source was evident from the results generated with the McLaren and Bowles (1985) method, by showing a radiating vector-pattern from station $\mathrm{J} 1$, and also to some extent by the LeRoux (1994a, b) method that produced vectors centered at stations $\mathrm{I} 2, \mathrm{H} 1, \mathrm{H} 3$, and $\mathrm{H} 4$ with directions either to the north or to the center of the bay. This source, however, would be difficult to identify using only the results of the LeRoux (1994a, b) method. Hydrographic data discussed for the southern end of the bay (Obeso Nieblas et al., 1996; Gutierrez de Velasco et al., 2006; Ponte et al., 2006) is consistent with the existence of this source. This is also supported by the results of PérezSoto (1995) that found the Cadejé Basin to be the largest potential contributor of sediment inside of the bay.

The existence of the Santispac-El Coyote source is not as clear. Only three stations were available for textural analysis (B1-B3) but they showed transport away from the Santispac-El Coyote area, with both the McLaren and Bowles (1985) and LeRoux (1994a, b) methods. The small drainages around Playas Santispac and El Coyote contribute 


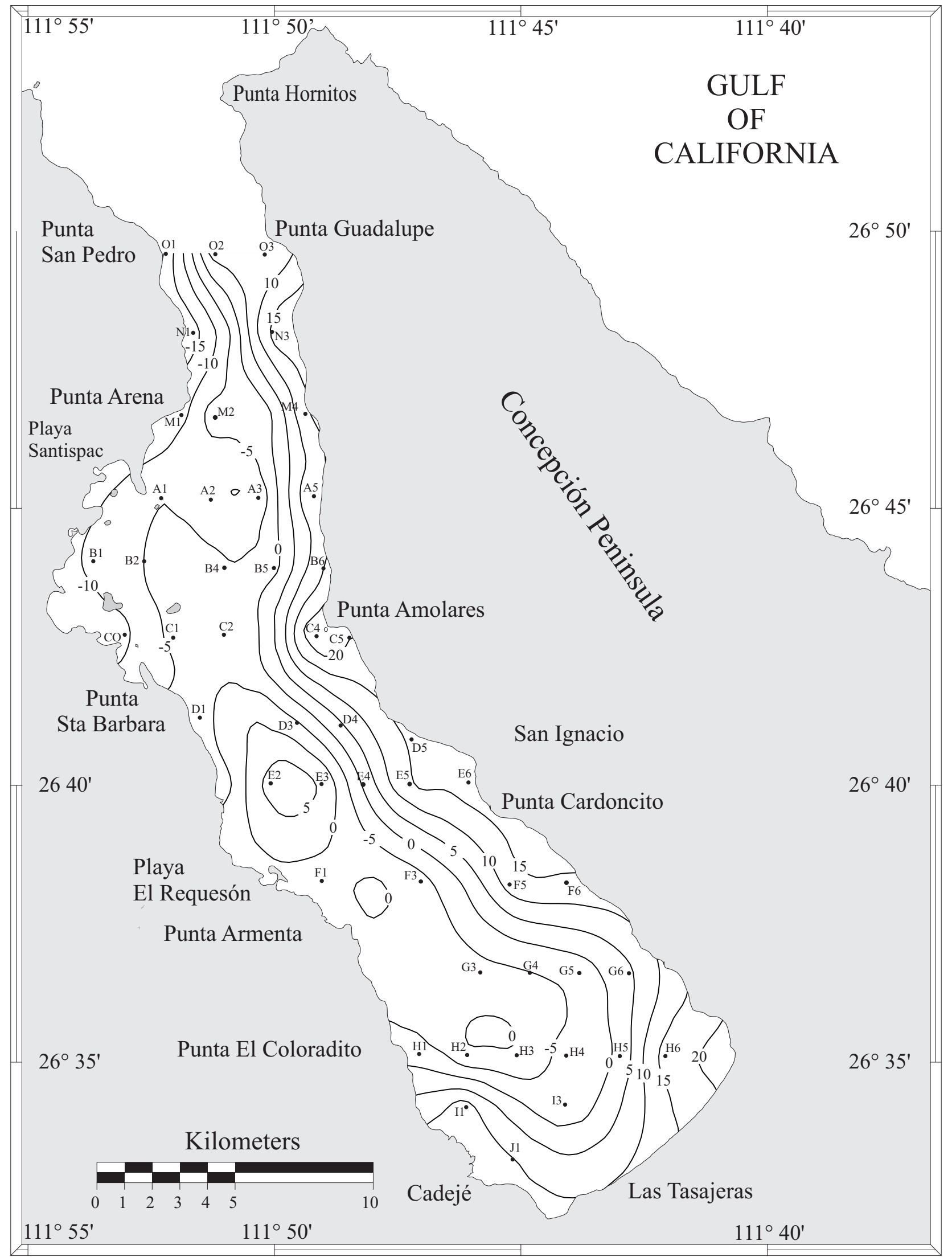

Figure 10. Principal component one (PC1) of the principal components analysis for the heavy mineral data of Bahía Concepción. It accounts for $26.1 \%$ of the variability and explains the behavior of biotite, diopside and enstatite 


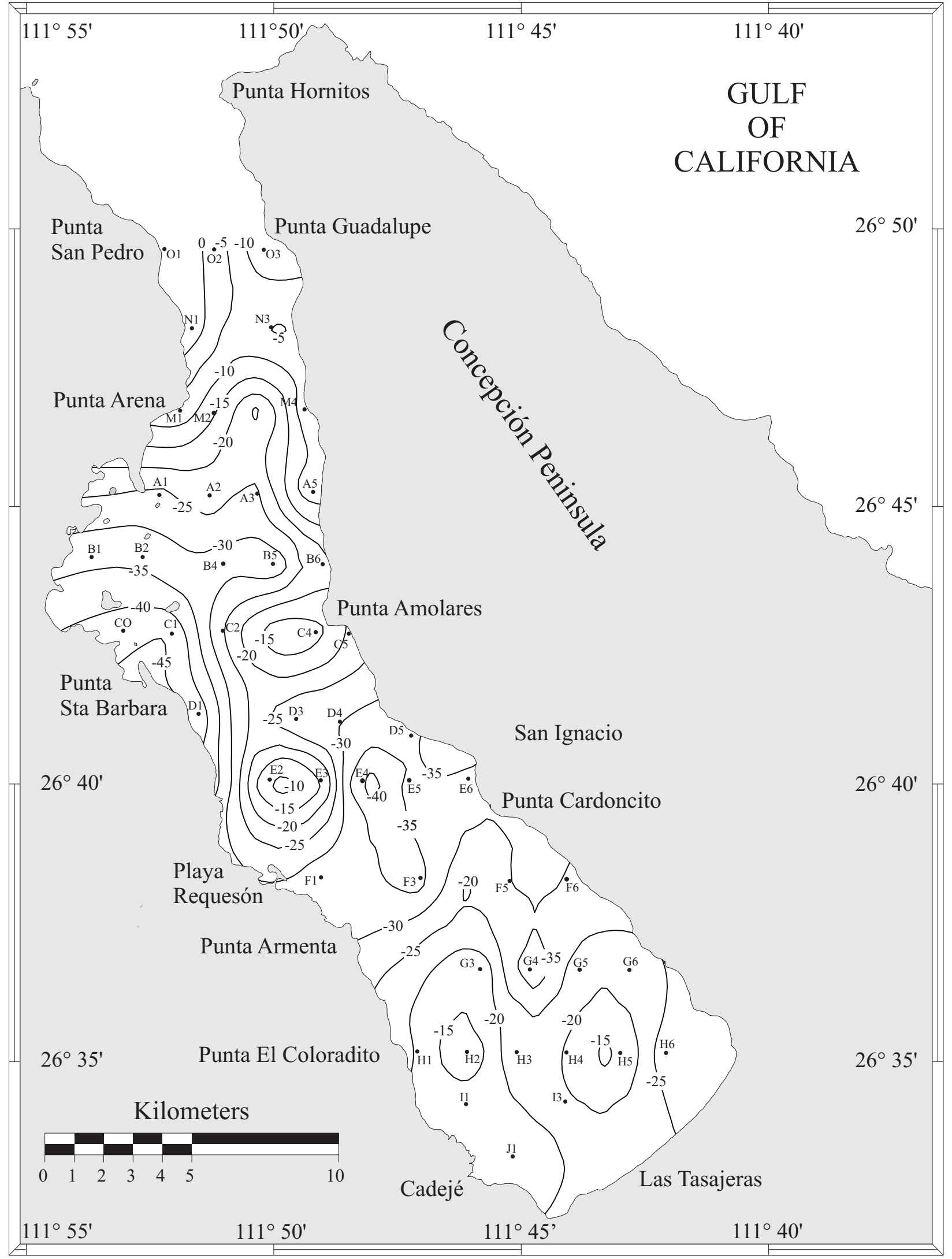

Figure 11. Principal component two (PC2) of the principal components analysis for the heavy mineral data of Bahía Concepción. It accounts for $22.7 \%$ of the variability and explains the behavior of olivine and augite. Higher values (positive to -20) indicate dominance of olivine. Lower (> negative than -20) values indicate dominance of augite 


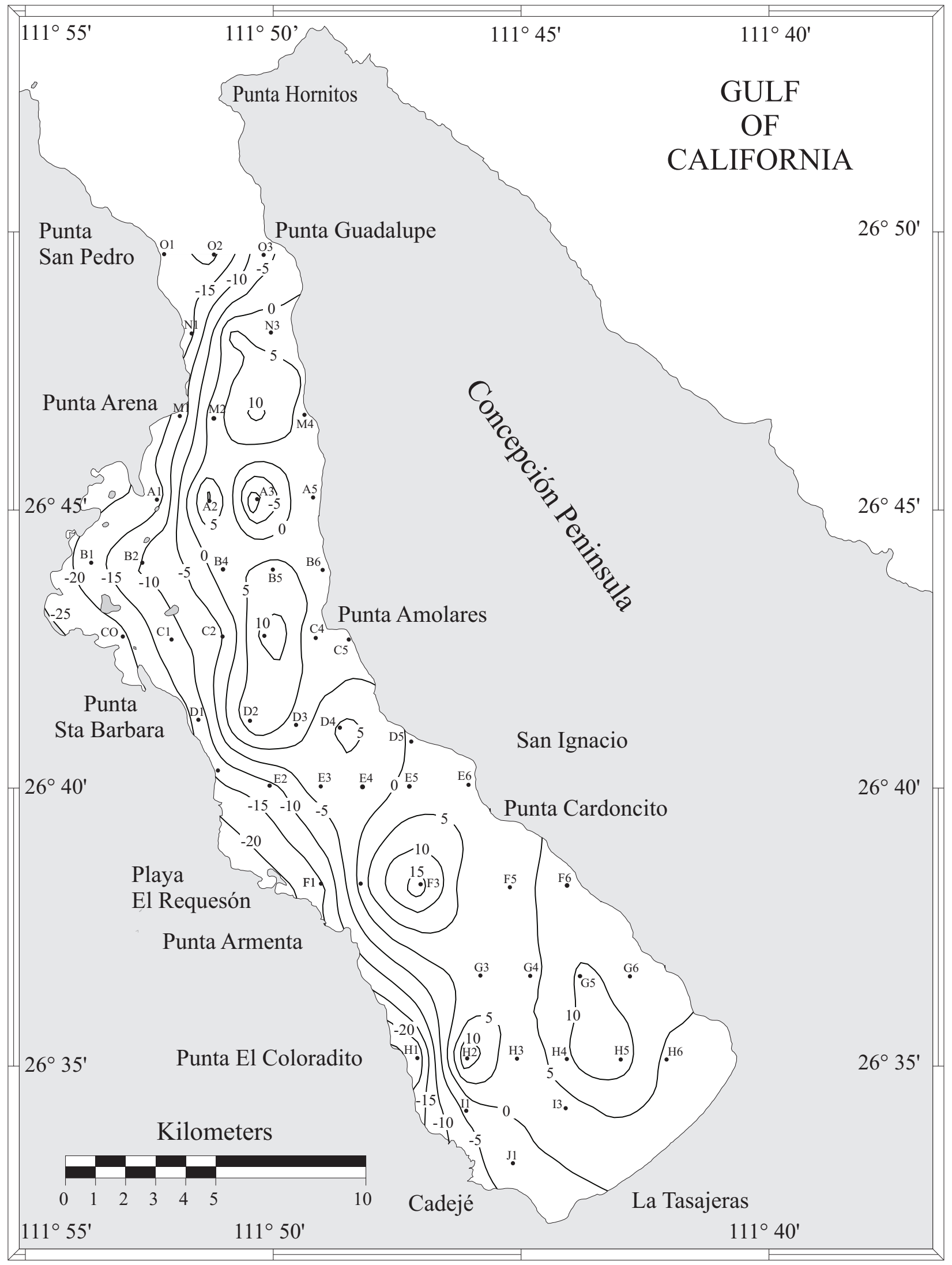

Figure 12. Principal component three (PC3) of the principal components analysis for the heavy mineral data of Bahía Concepción. It accounts for 15.4\% of the variability and explains the behavior of hypersthene and hornblende. Positive values indicate dominance of hornblende. Negative values indicate dominance of hypersthene. 


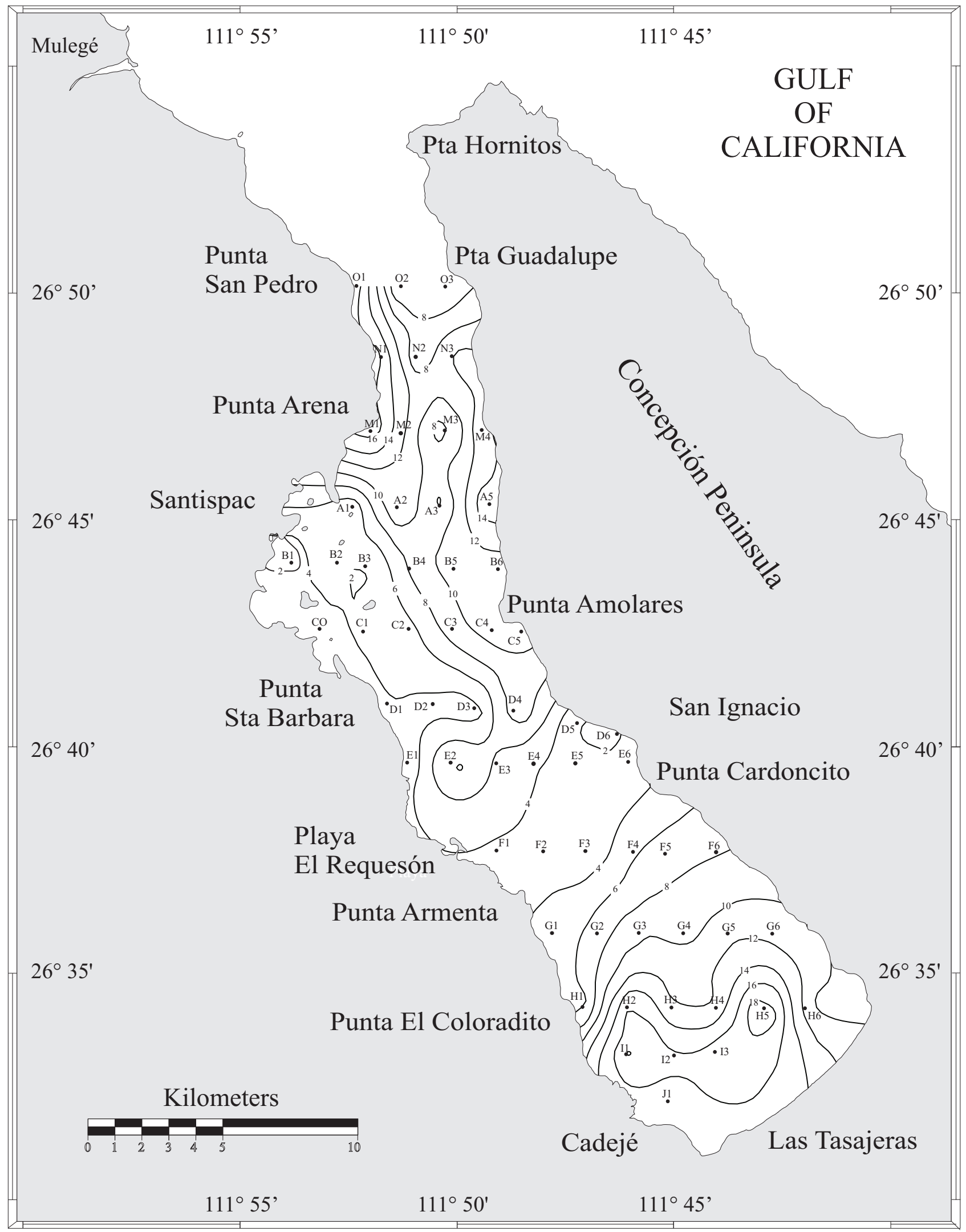

Figure 13. Percentage of olivine content in Bahía Concepción. Maximum values correspond to sampling stations H5 (21.1\%), I1 (18.4\%), M1 (17.5\%) and A5 (15.3\%) 
little clastic sediment to the bay since they tend to trap any sediment eroding from the surrounding watershed and are considered clastic-starved drainages (Meldahl et al., 1997). Pérez-Soto (1995) found that all the arroyos that drain into Bahía Santispac and El Coyote potentially contribute less than half the volume of sediment of that of Arroyo Cadejé near the head of the bay, and less than 10 percent of that of Río Mulegé. This area however is dominated by carbonate sands and their abundance decreases toward the axis of the bay from more than $75 \%$ in Santispac to less than $25 \%$ at mid-bay (Rodríguez-Meza et al., 2009). This suggests that this area is a carbonate exporter. This was also suggested by Meldahl et al. (1997) who described the areas of Playa Santispac and El Coyote as generators of carbonate sediments (mainly calcalgae-dominated sands) and capable of exporting this biogenic material into the bay.

For Bahía Concepción, the McLaren and Bowles (1985) method was found to be the best option since the bay's elongated nature made it possible to form transects with the required number of stations. The LeRoux (1994a, b) method showed a limited pattern of transport vectors with the available samples and produced only a few for the margins. For the Bahía Concepción case, the Le Roux model was a good complement because in some instances it provided an indication for lateral transport (west-east). This however could be a sampling problem; perhaps clearer results of the sediment trajectories would be obtained if we design a denser grid to include enough stations to form east-west transects with the McLaren and Bowles (1985) method, or use smaller spacing between samples to produce more vectors with the LeRoux (1994a, b) method, but with a considerable increase in time and resources to obtain and process samples.

\subsection{Clastic sediment provenance}

The findings in this study were consistent with van Andel's (1964) characterization of the western margin section of the Gulf of California surrounding Bahía Concepción as the Baja California augite province. He found augite to be the main heavy mineral present in sediment samples collected just north and south of the bay's entrance with an average of $54.6 \%$. We also found augite was the main heavy mineral in the interior of Bahía Concepción with values that range from a minimum of $19.5 \%$ to a maximum of $61.22 \%$ and corroborates the general idea of the volcanics of the Comondú Group as the source rocks for the bay. Other constituents of the heavy-mineral associations were also comparable to those found by van Andel (1964).

The total heavy mineral concentrations (Figure 9) suggest Arroyo Cadejé as the main source of clastic sediment to the bay with the highest concentrations of total heavy mineral radiating from Arroyo Cadejé and Station J1 towards station F3. This supports the existence of a depocenter for the southern half of the bay. They also show that almost all the rest of the clastic sediments being deposited in the bay come from the volcanics of the Concepción Peninsula, the most important being at Punta Amolares, with high concentrations radiating from arroyos arr11 and arr12, and station C4. But although these arroyos have high concentrations of heavy minerals, their drainage basins are very small with a combined potential sedimentyield of only $230 \mathrm{~m}^{3}$ compared to the Cadejé Basin potential yield of 1,460 $\mathrm{m}^{3}$ obtained by Pérez-Soto (1995) for the 1922-1988 period. The total concentration distribution of heavy minerals show that their dispersion is controlled by the steepness of the slopes as it follows the asymmetric nature of the bay's bathymetry (Figure 3). In the south the maximum depths are towards the western margin, as are the maximum concentrations of heavy minerals. North of Punta Amolares, the maximum depths are towards the eastern margins, as are also the highest concentrations of heavy minerals.

PC1 of the PCA for the heavy mineral data showed that the maximum concentrations for biotite, diopside and enstatite were at the eastern margin of the bay and decrease toward the western margin, suggesting east-west sediment transport. This agrees with the proposed depocenter at the central and deeper areas of the bay. The maximum concentrations for biotite, diopside and enstatite coincided with arroyos arr8, arr11 and arr13. These minerals are typically produced by metamorphic and igneous rocks like those reported as Cretaceous basement by McFall (1968) and Camprubí et al. (2008) at the Concepción Peninsula and outcrops of these rocks are located within the drainage area that feeds arroyos arr8 and arr11 (Figure 2). There are no Cretaceous basement rocks reported that could feed the arroyo arr13 maximum. The fact that PC1 values decrease from arroyo arr11 toward arroyo arr13 suggests that there is also a component of transport to the north and agrees with the modeled transport by the McLaren and Bowles (1985) and LeRoux (1994a, b) methods that show northward transport along the eastern margin.

For PC2 the more negative values correspond to augite dominance and less positive values to olivine dominance (Figure 11). For augite less negative values are found in the transport direction. PC2 showed that the maximum concentrations for augite were off Punta Santa Barbara (Arroyo La Enramada) and at the central part of the bay (station E4) and arroyo arr10. Arroyo La Enramada drains from a smaller basin than arroyos San Juan and Armenta, neighboring to the south, however surface-sediment facies distributions proposed by Meldahl, et al. (1997) and Rodríguez-Meza et al. (2009) give evidence of a larger contribution of clastic sediments from Arroyo La Enramada. Meldahl et al. (1997) showed that these arroyos drain clastic-starved basins that provide limited input of clastic sediment into the bay. The rock sources for augite are most likely those of the Ricasón Formation consisting of andesitic and basalt flows, agglomerates and tuffs reported by McFall (1968) and Camprubí et al. (2008). This component resulted in less negative values from Punta Santa Barbara along the 
western margin to just north of Punta Coloradito, which implies that is being transported to the south along this section, around the seamount known as El Frijol (Figure 3 ). Along most of the eastern margin the values become less negative to the north resulting in transport toward the bay's entrance. These trends agree with the modeled transport using the McLaren and Bowles (1985) method; the sediment along the western margin moves southward from Punta Santa Barbara to Playa El Requesón and the sediment for most of the eastern margin moves to the north. The sediment transport modeled with the LeRoux (1994a, b) method also agrees with the augite trends for the western margin but only with central and northern parts of the eastern margin. It was possible to calculate only one vector for the southern part of the eastern margin, making it difficult to compare with results from other methods; the one vector showed a west-east direction of transport.

In the southern end of the bay, olivine (Figure 13) corroborates the existence of a source at Arroyo Cadejé and station J1 and suggests a dispersion pattern similar to the one obtained with the McLaren and Bowles (1985) and LeRoux (1994a, b) methods. The concentration of olivine at Arroyo Cadejé (arr6) was the highest in the bay (18.91\%). Olivine is physicochemically unstable (Goldich, 1938) and to maintain high concentrations it must be close to the source and/or have a significant contribution. This seems to be the case for the relatively high concentrations $(>12 \%)$ found in the southern end of the bay.

Another area with high concentrations of olivine is the western margin from Punta Arena to Punta San Pedro, suggesting a southward dispersion that is not in agreement with the McLaren and Bowles (1985) method. We attribute this high concentration to a local effect; here the tidal currents are at a maximum and the Ricasón Formation rock-outcrops are subject to intense erosion, feeding the sediments to the tidal currents. At tidal flood, currents move sediment to the south and Punta Arena, almost at a right-angle, and promote deposition by creating a shadow of energy.

PC3 explains the behavior of hornblende, and hypersthene; positive values indicate a dominance of hornblende while negative values indicate the dominance of hypersthene. $\mathrm{PC} 3$ showed that the maximum concentrations for hornblende are at the deepest parts of the bay and toward the eastern margin. This suggests that the rock-sources are those of the Ricasón and Pelones formations outcropping in the Concepción Peninsula and that they are being transported to the west. Perhaps this is related to a lower density in relation to the other heavy minerals (Rittenhouse, 1943); they are suspended more readily and deposit at depth in a less energetic environment. The highest concentrations of hypersthene were along the western margin of the bay and their sources are most likely the andesitic and basaltic flows of the Ricasón Formation. There is no apparent trend of this mineral along the margin but it disperses toward the central and deeper parts of the bay controlled by the bathymetry.

\section{Conclusions}

The McLaren and Bowles (1985) method showed a bi-directional pattern of sediment transport at the entrance of the bay, in which sediment tends to be exported along the shallow areas and enters the bay through the deeper channel. For the rest of the bay, the McLaren and Bowles (1985) method showed a general transport direction to the north on the eastern margin, and to the south on most of the western margin. The exception to this pattern was the area just north of Arroyo Cadejé, where the direction of the sediment transport was toward the north and deeper parts of the bay.

Two cyclonic gyres were obtained with the LeRoux (1994a, b) method for the middle section of the bay and one anticlyclonic at the head.

Two main sources of sediment were identified for the bay; the area adjacent to Punta Cadejé was the main source of clastic sediments and the area between Playa Santispac and El Coyote, mainly exporting carbonates. The heavy mineral concentrations suggest that all the rest of the clastic sediments being deposited in the bay come from the volcanics of the Concepción Peninsula.

Olivine distribution was found to be a good means to corroborate the existence of a clastic source at Punta Cadejé.

The total concentration distribution of heavy minerals show that their dispersion is controlled by the steepness of the slopes as it follows the asymmetric nature of the bay's bathymetry.

The three methods used indicate sediment transport to the deeper parts of the bay and the existence of a depocenter located at or near stations F2 and F3, midpoint between Playa Requesón and Punta Cardoncito.

For this study, the McLaren and Bowles (1985) method was found to be the best fit due to the bay's elongated nature and the sampling design.

\section{Acknowledgments}

The original manuscript was greatly improved by Dr. Donn Gorsline's and Dr. Alberto Sánchez reviews, and Dr. Eduardo Santa María del Angel advice on the statistical analysis, we thank them very much. We appreciate the constructive comments of the reviewers. This research was supported by the Universidad Autónoma de Baja California and CONACyT's grant 4291P-T (1996-1997).

\section{References}

Baba, J., Peterson, C.D., Schrader, H.J., 1991, Modern fine-grained sediments in the Gulf of California, in Dauphin, J.P., Simoneit, B.R.T. (eds.), AAPG Memoir 47, 569-587. 
Caliskan, H., Valle-Levinson, A., 2008, Wind-wave transformations in an elongated bay: Continental Shelf Research, 28, 1702-1710.

Callahan, J., 1987, A nontoxic heavy liquid and inexpensive filter for separation of mineral grains: Journal of Sedimentary Research, 57, 765-766.

Camprubí, A., Canet, C., Rodríguez-Díaz, A.A., Prol-Ledesma, R.M., Blanco-Florido, D., Villanueva, R.E., López-Sánchez, A., 2008, $\mathrm{Ge} \neg$ ology, ore deposits, and hydrothermal venting in Bahía Concepción, Baja California Sur, Mexico: Island Arc, 17, 6-25.

Cheng, P., Valle-Levinson, A., Winant, C.D., Ponte, A.L.S., Gutierrez de Velasco, G., Winters, K.B., 2010, Upwelling-enhanced seasonal stratification in a semiarid bay: Continental Shelf Research, 30, 1241-1249.

Davis, J.C., 1986, Statistics and Data Analysis in Geology: New York, John Wiley and Sons, $656 \mathrm{p}$.

Duman, M., Avci, M., Duman S., Demirkurt, E.,Duzbastilar, M.K., 2004, Surficial sediment distribution and net sediment transport pattern in Izmir Bay, western Turkey: Continental Shelf Research, 24, 965-981.

Gao, S., Collins, M.B., 1992, Net sediment transport patterns from grainsize trends, based upon definition of "transport vectors": Sedimentary Geology, 81, 47-60.

Gao, S., Collins, M.B., 1994, Analysis of grain size trends, for defining sediment transport pathways in marine environments: Journal of Coastal Research, 10, 70-78.

Goldich, S.S., 1938, A study in rock-weathering: Journal of Geology, 46, 17-58.

Gonzalez-Yajimovich, O., Pérez-Soto, J.L., 1998, Patrón de dispersión de sedimentos modernos de Bahía Concepción, Baja California Sur (resumen), en Primera Reunión Nacional de Ciencias de la Tierra: México, D.F., Sociedad Geológica Mexicana, Instituto Nacional de Geoquímica, Sociedad Mexicana de Geomorfología, Sociedad Mexicana de Geomorfología, Sociedad Mexicana de Mineralogía, Asociación Mexicana de Geólogos Petroleros , 102.

Gutierrez de Velasco, G., Valle-Levinson, A., Ponte, A., Winant, C. Winters, K., 2006, Tidal and wind forcing in a semi-enclosed basin: Bahía Concepción: EOS Transactions, 87, 36

Lechuga-Devéze, C.H., Morquecho-Escamilla, M.L., Reyes-Salinas, A., Hernández-Alfonso, J.R., 2000, Environmental natural disturbance at Bahía Concepción, Gulf of California, in Munawar, M., Lawrence, S.G., Munawar, I.F., Malley D.F. (eds.), Aquatic ecosystems of México: Status and Scope: Leiden, Netherlands, Backhuys, 245-255.

Ledesma-Vázquez, J.R., Berry, W., Johnson, M.E., Gutiérrez-Sánchez, S., 1997, El Mono chert: A shallow-water chert from the Pliocene Infierno Formation, Baja California Sur, Mexico, in Johnson, M.E., Ledesma-Vázquez, J. (eds.), Pliocene Carbonates and Related Facies Flanking the Gulf of California, Baja California Mexico: Boulder, Colorado, GSA Special Papers 318, 73-81

Ledesma-Vázquez, J., Johnson, M.E., 2001, Miocene-Pleistocene tectonosedimentary evolution of Bahía Concepción region, Baja California Sur (México): Sedimentary Geology, 144, 83-96.

Leinen, M., Pisias, N., 1984, An objective technique for determining endmember compositions and for partitioning sediments according to their sources: Geochimica et Cosmochimica Acta, 48, 47-62.

LeRoux, J.P., 1994a, An alternative approach to the identification of net sediment transport paths based on grain-size trends: Sedimentary Geology, 94, 97-107.

LeRoux, J.P., 1994b, A spreadsheet template for determining sediment transport vectors from grain-size parameters: Computers and Geoscience, 20, 433-440.

Lewis, D.W., 1984, Practical Sedimentology: Stroudsburg, Pennsylvania, USA, Hutchinson Ross, 229 p.

López-Cortés, D.J., Gárate-Lizárraga, I., Bustillos-Guzmán, J.J., AlonsoRodríguez, R., Murillo-Murillo, I., 2003, Variabilidad del estado trófico y la biomasa del fitoplancton de Bahía Concepción, Golfo de California (1997-1999): Hidrobiológica, 13, 195-206.

Mange, M.A., Maurer, H.F.W., 1992, Heavy Minerals in Colour: London, Chapman and Hall, $160 \mathrm{p}$.

Mange-Rajetzky, M., 2003, Heavy minerals revisited; a brief review: Annual Report of the Hungarian Geological Institute 2002, 257-270.
McFall, C.C., 1968, Reconnaissance geology of the Concepcion Bay area, Baja California, Mexico: Stanford University Publications in Geological Sciences 10, 1-25.

McLaren, P., Bowles, D., 1985, The effects of sediment transport on grainsize distributions: Journal of Sedimentary Research, 55, 457-470.

Meldahl, K.H., Gonzalez-Yajimovich, O., Avila-Serrano, G., Empedocles, C., Gustafson, C., Motolinia-Hidalgo, M., Reardon, T., 1997, Holocene sediments and molluscan faunas of Bahía Concepción: a modern analog to Neogene rift basins of the Gulf of California, in Johnson, M.E., Ledesma-Vázquez, J. (eds.), Pliocene Carbonates and Related Facies Flanking the Gulf of California, Baja California Mexico: Boulder, Colorado, GSA Special Papers 318, 39-56.

Morquecho, L., Lechuga-Devéze, C.H., 2003, Dinoflagellate cysts in recent sediments from Bahía Concepción, Gulf of California: Botanica Marina, 46, 132-141.

Nava-Sánchez, E.H., Gorsline, D.S., Molina-Cruz, A., 2001, The Baja California peninsula borderland: structural and sedimentological characteristics: Sedimentary Geology, 144, 63-82.

Obeso Nieblas M., Alatorre Mendieta, M.A., Jimenez Illescas, A.R., 1996, Modelación de la marea en Bahía Concepción, B.C.S., México: Oceánides, 11, 1-8.

Pérez-Soto, J.L., 1995, Volumen de sedimento drenado a Bahía Concepción, Baja California Sur, México (1922-1988): Ensenada, Baja California, Universidad Autónoma de Baja California, Bachelor Thesis, 26 p.

Pérez-Soto, J.L., 1998, Origen y patrón de dispersión de los sedimentos superficiales en Bahía Concepción, Baja California, Sur, México: Ensenada, Baja California, Universidad Autónoma de Baja California, Master's Thesis, $76 \mathrm{p}$.

Ponte, A.L., Valle-Levinson, A., Winant, C., Gutierrez de Velasco, G., Winters, K., 2006, Drifters observation in a bay driven by wind and tide: Bahía Concepción (abstract): Honolulu, Hawaii, Ocean Science Meeting.

Price, W.A., 1963, Patterns of flow and channeling in tidal inlets: Journal of Sedimentary Research, 33, 279-290.

Rendón-Márquez, G., 1995, Técnicas petrográficas para el estudio de rocas y sedimentos en el laboratorio de petrología de CICESE: Ensenada, Baja California, Centro de Investigación Científica y de Educación Superior de Ensenada, Comunicaciones Académicas, Technical Report, 33 p.

Rittenhouse, G., 1943, Transportation and deposition of heavy minerals: Geological Society of America Bulletin, 54, 1725-1780.

Rodríguez-Meza G.D., Shumilin, E., Sapozhnikov, D., Méndez-Rodríguez L., B. Acosta-Vargas, 2009, Evaluación geoquímica de elementos mayoritarios y oligoelementos en los sedimentos de Bahía Concepción (B.C.S., México): Boletín de la Sociedad Geológica Mexicana, 61, 57-72.

Sánchez, A., Alvarez-Legorreta T., Sáenz-Morales, R., Ortiz-Hernández, M.C., López-Ortiz B.E., Aguíniga, S., 2008, Distribución de parámetros texturales de los sedimentos superficiales en la Bahía de Chetumal: Implicaciones en la inferencia de transporte: Revista Mexicana de Ciencias Geológicas, 25, 523-532.

Valle-Levinson, A., Gutierrez de Velasco, G., Ponte, A., Winant, C., Winters, K., 2006, Spatial structure of wind-induced flow in a rotating semienclosed basin: Bahía Concepción: Honolulu, Hawaii, Ocean Science Meeting, 36.

Van Andel, T.H., 1964, Recent marine sediments of the Gulf of California, in Van Andel, T.H., Shor, G.G. (eds.), Marine Geology of the Gulf of California: Tulsa, Oklahoma, USA, AAPG Memoir 3, 216-310.

Wright, D.J., Scholz, A.J. (eds.), 2005, Place Matters: Geospatial Tools for Marine Science, Conservation and Management in the Pacific Northwest: Corvallis, Oregon, Oregon State University Press, 305 p.

Manuscript received: June 10, 2010.

Corrected manuscript received: August 1, 2010.

Manuscript accepted: August 10, 2010. 